Bu makaleye atıfta bulunmak için/To cite this article:

HASTAOĞLU, E. ERDOĞAN, M. IŞKIN, M. (2021). Gastronomi Turizmi Kapsamında Türkiye Peynir Çeşitliliği

Haritası. Atatürk Üniversitesi Sosyal Bilimler Enstitüsü Dergisi, 25 (3), 1084-1113.

\title{
Gastronomi Turizmi Kapsamında Türkiye Peynir Çeşitliliği
}

\section{Haritası}

\author{
Emre HASTAOĞLU (*) \\ Melda ERDOĞAN ${ }^{(* *)}$ \\ Mustafa IŞKIN ${ }^{(* * *)}$
}

Öz: Peynir, çok eski zamanlardan bu yana tüketilen besleyici bir gıdadır. Peynir tarımla uğraşan tüm toplumlarda klymetli bir glda maddesi olarak görülmektedir. Dünya'nın birçok bölgesinde üretilen peynir o bölgelerin yeme-içme ve tarım kültürünü de bize göstermektedir. Dünya mutfağında vazgeçilmez bir gıda maddesi olan peynir ülkelerin kültür zenginliğinin bir parçasıdır. Peynirin çeşitliliğini etkileyen faktörlerden bazıları ise o ülkenin kültürüne ve mutfağına verdiği önemden geçmektedir. Peynir insan sağlı̆̆ açısından bakıldiğında da çok önemli bir yerdedir. Peynir, D vitamini, protein, kalsiyum, çinko gibi önemli besin değerlerine sahiptir. Türkiye'deki bitki örtüsü ve iklim çeşitliliği nedeniyle peynirin hammaddesi olan sütün yapısında da farklılıklar oluşabilmektedir. Hemen hemen her kültürde, her bölgede farkl tekniklerle üretilen peynirin üretim süreçlerinde, süt ve diğer hammaddeler birçok teknik aşamadan geçerek peynire dönüşmektedir. Teknolojinin gelişimi ile birlikte peynir üretim süreçleri de modernize edilmiştir. Sütün yanı sıra üretim teknikleri ve yörenin florası da üretilen peynirlerin çeşitlenmesine neden olmuştur. Bu çeşitlilik endüstriyel ve geleneksel peynir pazarının genişlemesine ve farkl peynir arayışııda olanların ilgisini çekmektedir.

Bu araştırmada, Türkiye'deki bölgelere göre farklılı gösteren peynir çeşitlerinin özelliklerinin belirlenmesi ve iç turizmde yeni destinasyonlartn belirlenmesinde etkili olacăg düşünülen peynir rotalarının oluşturulması amaçlanmıştır. Bu amaç doğrultusunda; Türkiye'nin yedi coğrafi bölgesinde toplam 75 peynir çeşidinin üretimi ve özellikleri veri araştırllmıştır. Bunlardan 21 tanesinin besin öğelerinin karşılaştırılması yapılmıştır. Araştırmanın devamında endüstriyel olarak en çok üretimi gerçekleşen beyaz peynir (4), kaşar peyniri (6), tel peynir (6), tulum peynir (7), otlu peynir (6), haşlama peynir (6) olmak üzere 35 adet endüstriyel peynirin teknik özellikleri ve farklılıkları araştırılmıştır.

Elde edilen sonuçlara göre, kullanılan sütün cinsi (inek, koyun, keçi), pıhtı oluşturma yöntemleri (asit, şirden, maya), kullanılan yă̆ oranı (tam yağlı, az yağlı gibi.), tuz oranı (az tuzlu, tuzlu, tuzsuz), protein düzeyi, sütün işlem görmesi (pastörize, çiğ), kullanılan otlar ve baharatlar, olgunlaşma süresi (olgun, taze), iklim, hava sıcaklı̆̆l, alışkanlıklar, doğal mikroflora, gelenekler ve imkanlar gibi birçok etken doğrultusunda Türkiye'deki peynirlerin çeşitlendiği tespit edilmişstir.

*) Dr. Öğr. Üyesi, Sivas Cumhuriyet Üniversitesi Turizm Fakültesi Gastronomi ve Mutfak Sanatları Bölümü (e-posta: ehastaoglu@cumhuriyet.edu.tr) (D) ORCID ID. https://orcid.org/0000-0001$8802-6632$

**) Dr. Öğr. Üyesi, Sivas Cumhuriyet Üniversitesi Sosyal Bilimler Enstitüsü Turizm İşletmeciliği Anabilim Dalı (e-posta: mld.erdgn1@outlook.com.tr ) (D ORCID ID. https://orcid.org/00000002-0812-5305

***) Dr. Öğr. Üyesi, Sivas Cumhuriyet Üniversitesi Turizm Fakültesi, Gastronomi ve Mutfak Sanatları Bölümü (e-posta: mustafaiskin@cumhuriyet.edu.tr) (DORCID ID. https://orcid.org/0000-0002-5097-2268

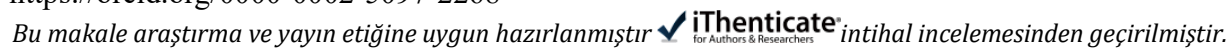


Söz konusu çeşitlilik unsurlarından önemli olan ve gastronomi turizmi kapsamında turizm hareketlerine katılan turistlere rota belirlemede yardımcı olabilecek, peynirin yağ, protein oranları ve kullanılan otlar ve baharatlara göre destinasyon düzeyinde sinıflandırma yapılmıştır. Böylelikle hangi destinasyonlarda ne tarz peynirlerin bulunduğu belirlenmiştir. Bu doğrultuda gastronomi faaliyetlerine katılan turistler için rotalar belirlenmiştir.

Anahtar Kelimeler: Peynir, peynir üretimi, peynir türleri, süt, Türkiye'de peynir çeşitleri.

\section{Turkey Cheese Diversity Map within the Scope of Gastronomy Tourism}

Abstract: Cheese is a nutritious food that has been consumed since ancient times. Cheese, which is produced with different techniques in almost every culture, in every region, goes through many technical stages. With the development of technology, cheese production has also been modernized. Cheese has become a valuable food item in all societies engaged in agriculture. Cheese produced in many parts of the world also shows us the food, beverage and agricultural culture of those regions. Cheese, which is an indispensable food item in world cuisine, is a part of the cultural richness of countries. Some of the factors affecting the diversity of cheese are the importance given to the culture and cuisine of that country. Cheese has a very important place in terms of human health. Cheese has important nutritional values such as vitamin D, protein, calcium and zinc. Due to the diversity of vegetation and climate in Turkey, there may be differences in the structure of milk, which is the raw material of cheese. In addition to milk, production techniques and the flora of the region have also led to the diversity of the cheeses produced. This variety attracts the expansion of the industrial and traditional cheese market and the interest of those who are looking for different cheeses.

In this research, it is aimed to determine the characteristics of cheese varieties that differ according to regions in Turkey and to create cheese routes that are thought to be effective in determining new destinations in domestic tourism. In accordance with this purpose; The production and characteristics of a total of 75 cheese varieties in seven geographical regions of Turkey were investigated. Comparison of the nutritional elements of 21 of them was made. In the continuation of the research, the most industrially produced white cheese (4), cheddar cheese (6), string cheese (6), tulum cheese (7), herbed cheese (6), boiled cheese (6), the technical analysis of 35 industrial cheeses. characteristics and differences were investigated.

When the results are evaluated, the variety of cheese in our country, the type of milk used (cow, sheep, goat), the methods of forming clots (acid, shirden, yeast), the rate of fat (full fat, low fat, etc.), salt rate (low salt, salty). Cheese variety has developed due to many factors such as milk, unsalted), processing of milk (pasteurized, raw), herbs and spices used, ripening time (ripe, fresh), climate, air temperature, habits, natural microflora, traditions and possibilities. When the nutritional values of the local cheeses produced in Turkey were compared, it was seen that Trakya old kashar cheese had the highest energy value and Erzurum civil cheese had the lowest energy value.

Keywords: Cheese, cheese production, cheese types, milk, cheese types in Turkey

Makale Geliş Tarihi: 26.06.2021

Makale Kabul Tarihi: 20.09.2021

DOI: 10.53487/ataunisosbil.898327 


\section{Giriş}

Sütün beslenmemizdeki önemi her geçen gün artmaktadır. Güncel beslenme piramidinde de en sık tüketilmesi gereken besin grubu olarak karşımıza çıkmaktadır. Sadece süt değil, süt ürünleri de benzer besin değerine sahip olup süt ürünlerin tüketim miktarı ve tüketim şekli toplumlara göre değişiklik göstermektedir. Özel beslenme grupları olan bireylerin süt ve süt ürünlerinden bir veya birkaçını tüketmemekte ve tüketemediklerinin yerine ikame başka süt ürünlerini tercih etmektedirler. Bununla birlikte sütün bileşimi, yöreden yöreye bölgeden bölgeye değişebilmektedir. Türkiye'nin doğu bölgesindeki süt veren bir inekle iç bölgesinde süt veren ineğin süt kalitesinde, sütün aromasında ve bileşiminde farklılıklar görülmektedir. Bunun birçok sebebi vardır. Hayvanın ırkı, beslenme şekli, yaşı, bulunduğu ortamdaki sıcaklık gibi birçok etken sütün kalitesini de etkilemektedir (Tarakçı, Bölük ve Karaağaç, 2015: 53). Sütteki bu farklılıklar süt ürünlerinin de lezzet, yapı, renk gibi birçok özelliğini etkilemektedir.

Peynir dünyada olduğu gibi Türkiye'de en sık tüketilen süt ürünlerindendir. Sütün kalitesinin iyi olması sütten üretilmiş olan peynirinde kalitesini etkilemektedir. Bugün peynir mutfaklarımızın vazgeçilmez bir parçasıdır. Peynir bir mutfağın kültürünün yansımasıdır. Çok eski tarihlerden bu yana peynir tüm dünya mutfağında çok önemli bir değere sahiptir.

Gastronomi turizmi giderek önemi ve çeşitliliği artan dinamik bir turizm çeşididir. Farklı yiyecek veya içecekleri deneyimlemek üzere insanlar seyahat etmektedirler. Bu seyahatlere konaklama, ibadet ve iş gibi farklı amaçlar da eklenebilmektedir. Peynir rotaları sayesinde farklı destinasyonlarda farklı peynirleri tadım yapma ve satın alma amaçlarıyla insanlar peynir turizmi gerçekleştirebilmektedir.

\section{Peynir, Üretimi ve Tarihçesi}

Peynir, dünya çapında çok çeşitli tat ve şekillerde üretilen fermente süt ürünlerindendir. Önceleri sadece süt bileşenlerini korumanın bir yolu olarak, peynir, son derece besleyici olmasının yanı sıra, epik niteliklere sahip bir yüksek mutfak ürünü haline gelmiştir. Dünyada 1000 'den fazla peynir çeşidi olduğunu öne sürülmekte olup, araştırmacıların çoğu 400 ile 500 arasında peynir çeşidi tanımlayabilmişlerdir (Fox, 1993: 6).

Peynirin yaklaşık 8000 yıl önce Irak'ta Dicle ve Fırat arasındaki “Bereketli Hilal”de evrimleştiğine inanılmaktadır. Sözde “Tarım Devrimi” burada bitki ve hayvanların evcilleştirilmesiyle gerçekleşmiştir. İnsanoğlu kısa süre sonra evcil hayvanlarının ürettiği sütün besleyici değerini anlamış ve annenin sütünü yavrularıyla paylaşmayı başarmıştır. Ne yazık ki, süt aynı zamanda sütü kirleten bakteriler için de zengin bir besin kaynağıdır. Bazı türleri enerji kaynağı olarak süt şekeri, laktozu kullanır ve yan ürün olarak laktik asit üretir. Bakteriyel büyüme ve asit üretimi, depolama sırasında veya daha stabil bir ürün üretmek için sıcak ve kuru iklimde sütü kurutma girişimleri sırasında meydana gelmiştir. Yeterli asit üretildiğinde, sütün temel proteinleri olan kazeinler, yağ 1 
hapseden bir jel oluşturmak üzere izoelektrik noktalarında pıhtılaşmış ve böylece dünyanın ilk fermente süt ürünleri tesadüfen üretilmiştir (Fox, 1993: 6).

Bazı kaynaklarda peynirin ilk olarak çobanlar tarafından keşfedildiği de yazmaktadır. Bazı kaynaklarda ise sütün tesadüfen ekşidiğine değinilmektedir. Kanada için yapılan gezide koyunun midesinde taşıdığı sütün tesadüfen pihtılaşmasıyla peynirin ortaya çıktığı söylenmektedir. Başka kaynaklara göre ise İskit Türklerinin kısrağ ehlileştirmesinden sonra kısrak sütünü ekşitip peyniri bulduğu söylenmiştir. Somut bir kaynak bulunamamasıyla birlikte ilk peynirin Mezopotamya topraklarında yapıldığı kabul görülmüştür. Türklerin Anadolu'ya göçü sonrasında peynir sözcüğünün dilimize geçtiği görülmektedir (Bekiroğlu, 2019: 6).

İnek, koyun ve keçi gibi hayvanların ehlileştirilmesinden sonra hayvanların sütünden faydalanılmış süt, artık bir gıda olarak kullanılmaya ve işlenmeye başlamıştır. Öyle ki sütün ilk işlenmesinin Mezopotamya topraklarına kadar dayandığı yazıtlarda ve sütunlarda önümüze çıkmaktadır. Kaşgarlı Mahmut'un Divan-i Lügat-it Türk kitabında da peynirden bahsedilmiştir. "udma- udhıtma" adıyla geçmiştir. Peynir Farsçadan dilimize dahil edilmiştir. Dede Korkut'ta kitabında peynire yer vermiştir. Peynirin insan sağlığı açısından birçok faydası bulunmaktadır. Kutsal kitap Tevrat'ta dahi peynir faydasından öneminden bahsedilmişsir (ankaratb.org.tr).

Osmanlı mutfak kültürüne bakıldığında süt ve sütten imal edilen peynir, kaymak yapımının öğrenildiği ve mutfak kültürüne dahil edildiği görülmektedir. Farklı peynir çeşitleri ilgi çekmiş, bu peynirlerle farklı yemekler denenmiş ve bu dönemde dışarıdan ithal peynirler getirilmeye başlanmıştır. Bu peynirlere örnek olarak "parmezan" peyniri örnek gösterilebilir (Durlu ve Gün, 2008: 4)

Peynirin üretimi yöreden yöreye değişmekle birlikte temelde süt proteini olan kazeinin enzim veya starter kültür (mayalanma sürecini hızlandırıp yönlendirerek istenen özelliklerde fermente gıda üretmek amaciyla hammaddeye katılan mikroorganizma kültürü) ile pıhtılaşması sonucu serbest kalan peynir altı suyunun uzaklaşması ve sertleşen pıhtının yapı oluşumunun tamamlanmasına dayanır. Burada peynirleri birbirinden ayıran özellikler starter kültür kullanılıp kullanılmadığı, starter kültürün özellikleri, olgunlaşma şartları, sütün bileşimi, hayvanın beslenme şartlarıdır. $\mathrm{Bu}$ nedenlerle, günümüzde her yörenin kendine has peyniri bulunmaktadır.

Türkiye'de yoğun bir peynir çeşitliliği bulunmakla birlikte özellikli peynir turizm rotaları oluşturulmamıştır. Fransa'da ve İtalya'da var olan peynir gezileri sayesinde bölgesel kalkınma, tanınırlık ve sürdürülebilir tarım faaliyetleri hız kazanmıştır (Cihangir ve Demirhan, 2020: 140). Bu faaliyetler hem süt endüstrisine hem de turizm endüstrisine büyük katkılar sağladığı görülmüştür (Atış ve Çelikoğlu, 2017: 35; Kan, Gülçubuk ve Küçükçongar, 2010: 16) 


\section{Bölgelere Göre Peynir Çeşitleri}

\section{A. Marmara Bölgesi}

Marmara Bölgesi peynir üretimi açısından sanayileşmiş bir üretim şekline sahiptir. Üretim genellikle mandıralarda ya da fabrikalarda yapılmaktadır. Bölge gelirinin büyük bir çoğunluğunu peynir üretimi ve büyükbaş küçükbaş hayvan yetiştiriciliğinden kazanmaktadır. Bu bölgede genellikle İnek ve Sığır yetiştiriciliği yapılmaktadır, üretim yerleri genellikle; Edirne, Çanakkale, Tekirdağ, Balıkesir, Kırklareli’dir. Kırklareli peynir üretimi açısından bölgenin liderliğini ele almış durumdadır. Bölgede yetiştirilen bir diğer küçükbaş hayvan ise kıvırcık koyun türüdür. Bu türün sütü oldukça kıymetlidir ve süt verimi $62-89 \mathrm{~kg}$ arasında değişim göstermektedir (Ceyhan, Erdoğan ve Sezenler, 2007: 213). Kıvırcık koyun sütünden elde edilen peynirlerin lezzetleri diğer peynir çeşitlerine oranla daha kalitelidir ve daha çok tercih edilmektedir.

Her bölge kendi gelişim düzeyine bağlı olarak piyasaya sunduğu peynir çeşitlerine sahiptir. Marmara Bölgesi'ndeki peynir çeşitleri ise; Edirne beyaz peyniri, Ezine beyaz peyniri, Bursa Mihaliç peyniri, Abaza peyniri, Kırklareli peyniri, Trakya Eski kaşarı, Çerkez peyniri ve kaymaklı lor bölgenin en kıymetli peynirlerindendir. Edirne ve Ezine peynirleri coğrafi tescil altındadır.

Edine Beyaz Peyniri: Bölgenin kıymetli peynirlerinden Edirne beyaz peynirinin üretimi salamura yöntemiyle ya da tenekeleme yöntemiyle yapılmaktadır. Edirne beyaz peyniri ülkemizin birçok bölgesinde üretilmesine rağmen yoğunlukla üretimi Marmara Bölgesi'nde yapılmaktadır. Kendine özgü yapısı, tadı ve kokusu olan peyniri farklı kılan ise Edirne'nin coğrafi bölgesi ve o bölgedeki sütün çeşidine göre farklılık göstermesidir. Bir diğer etken ise peynirin yapısıdır, bu yapıya etki eden salamurada tuzlanarak olgunlaştırılmasıdır ve bu sayede peynirin yapısının gözenekli ya da düz bir yapıya sahip olmasıdır (Durlu ve Gün, 2008: 3). Ülkemizde en yaygın tüketilen coğrafi işaretli peynir çeşididir (Saygıl1, Demirci ve Samav, 2020: 15).

Ezine Beyaz Peyniri: Marmara Bölgesi’nde üretilen beyaz peynir çeşitleri arasında coğrafi işaretli olan bir peynirdir. Peyniri diğer peynirlerden özel kılan koyun, keçi, inek sütünün birleşmesinden elde edilmesidir (Özdemir ve Dülger, 2018:11). Ezine peynirin rengi açık sarıdır, orta sertliktedir ve kırılgan bir yapıya sahip değildir (Saygılı vd., 2020: 16).

Mihaliç Peyniri: Bursa, Balıkesir Karacabey civarlarında üretilmektedir. Bölgede peynirin bir diğer adı kelle peyniridir. Kalitesini tam yağlı koyun ve kıvırcık koyun sütünden almaktadır (Bulut, 2006). Üretim tekniği açısından yapımı kaşar peynirine benzeyen Mihaliç peyniri, keskin kokulu, gözenekli ve biraz tuzlu bir peynir çeşididir olmasıdır (Durlu ve Gün, 2008: 4)

Abaza Peyniri: Genel olarak koyun, keçi, inek ve manda sütünden üretilmektedir. Füme ya da taze olarak üretimi yapılmaktadır. Abazalar tarafından üretilen bir peynir çeşididir (Bekiroğlu, 2019: 52). 
Kırklareli Peyniri: Kırklareli peyniri üretildikten sonra 6 ay buzhanede bekletilmektedir. Koyun sütünden yapıldığı gibi, koyun sütüne keçi sütü katılarak da yapılmaktadır. İnek sütünden üretilen Kırklareli peyniri biraz daha sert bir yapıya sahiptir, peyniri özel kılan bir diğer unsur ise doğal maya kullanılmasıdır (kirklareli.gov.tr, 2021).

Trakya Eski Kaşarı: Kars kaşar peyniriyle karıştııılmaktadır. Kars kaşar peyniri genellikle inek sütünden üretilmektedir. Trakya eski kaşar peyniri ise küçükbaş hayvanların sütünden üretilmektedir. Peynire sarımtırak rengini ise kullanılan süt vermektedir. Üretimi yapıldıktan sonra 30-60 gün içerisinde tuzlama yöntemiyle olgunlaştırılır (peynirler.gen.tr,2020).

İsli Çerkez Peyniri: İnek veya koyun sütünün işlenerek üretilen yöresel bir peynir çeşididir. Peyniri özel kılan ekşi peynir suyu kullanılmasıdır. Tuzlama yöntemiyle olgunlaştırılıp, birkaç gün soğuk bir ortamda bekletilir. Olgunlaşan peynir 1 hafta boyunca islenir. Uzun ömürlüdür. Yapı olarak yumuşak bir peynirdir (Acar ve Karaosmanoğlu, 2019: 192).

\section{B. Ege Bölgesi}

Bölgede üretilen peynirlerin büyük çoğunluğu koyun ve keçi sütünden üretilmektedir (Bekiroğlu, 2019: 71). Yörüklerle birlikte deri tulum tekniği öğrenilmiş ve tenekede salamura ile yeni bir şekil ve ticari kazanç sağlamıştır. Salamuralı tulum tekniğinin ilk ortaya çıktığı yer Bergama'dır. Bölgenin temsilciliğini sepet peyniri taşımaktadır. Bölgenin meşhur peynirleri; Kirlihanım, Sepet peyniri, Koponesti peyniri, İzmir tulum peyniri, Sepet loru, İzmir Ödemiş teneke tulumu, Tire çamur peyniri gibi peynir çeşitleri bulunmaktadır.

Kirlihanım Peyniri: Lor peynirin üretimiyle benzerlik göstermektedir, peynir altı suyuyla üretilir tuzsuz ve yağsız bir yapıdadır. Olgunlaşmasında küflendirme yöntemi kullanılmıştır. $\mathrm{Bu}$ küf peynire kendine özgü koku, tat ve lezzet vermektedir (peynirrehberi.com, 2021).

Sepet Peyniri: Sepet peyniri Ege Bölgesi'ne ait y1llardan bugüne üretimi hala etmekte olan geleneksel bir peynir çeşididir. Bu peynirin yapımı göçmenlerden kültürümüze kazandırılmıştır. Peynire şekil verilirken sepetlerden yararlanılmaktadır. Sepet peyniri imalatında genellikle yün ve keçi sütü kullanılır (Ercan, 2009: 15). Sepet peyniri az tuzludur ve çoğunlukla gözenekli bir yapıya sahiptir ve Mihaliç peynirine de benzemektedir (Kınık, Ergüllü ve Akbulut, 1999: 152).

Koponesti Peyniri: Genellikle İzmir bölgesinde üretilen Yunan menşeli bir peynir çeşididir. Ege ve Yunan adalarında meze olarak sofralarda yer bulur. Koponesti ismi Yunancadan dilimize geçmiştir ve Türkçede karşıllğı dövülmüştür. Peynir bu adı yapım aşamasından almaktadır, lor peyniri iyice yoğurularak bir kaba alınır ve tuzlanarak muhafaza edilir. Peynirin kıvamı yoğurt kıvamındadır ve rengi koyu sarı ile açık 
kahverengi arasındadır. Tuzlu ve aroması yoğun bir peynir çeşididir (Kamber ve Çelik, 2007: 12).

İzmir Tulum Peyniri: İzmir tulum peynirinde genellikle koyun keçi ve inek sütü karıştırılarak kullanılır. Mandıralarda ya da fabrikalarda üretildiğinde teneke kutularda paketlendiği için Teneke tulum peyniri denir ancak hayvan derilerinde depolandığında salamura tulum peyniri denir. Genel olarak rengi beyazdır ama kullanılan sütün türü, peynirdeki tuz oranı rengi etkiler. Sert ve tam yağlı bir peynir çeşididir. Kendine ait aroması ve tadı vardır (Kamber ve Çelik, 2007: 13).

Ayvalık Sepet Loru: Sepet peyniri ya da Kirlihanım peynirinin peynir altı suyundan elde edilmektedir. Rengi sarımtıraktır. Genellikle inek, koyun ve keçi sütlerinden üretilir az tuzludur yemeklerde tatlllarda tercih edilir çoğunlukla (Durlu ve Gün, 2008: 4)

Tire Çamur Peyniri: İzmir'in Tire ilçesinde imalatı yapılmaktadır. Çoğunlukla peynir yerel halk tarafından tüketilmektedir. Koyun keçi sütünden üretildiği gibi son zamanlarda inek sütünden de imal edilmektedir. Peynir altı suyuna süt eklenir daha sonra İzmir tulum peynirinin salamurası da eklenip kıvam verilir. Kahvaltılarda ekmeğe sürülerek yenilen yöresel bir peynirdir (Kamber ve Çelik, 2007: 14).

Armola Peyniri: İzmir'in Seferihisar ilçesinde üretimi yapılmaktadır. Kırıntı tulum peynirinin üzerine yoğurt ilave edilir birkaç gün ardından keçi sütü ilave edilerek tulumlara konur 10-15 gün sonra tüketimi hazır hale gelmektedir. Peynir yapı olarak sürülebilir kıvamda tat olarak ise ekşimtıraktır ve tuzlu bir peynir çeşididir (Eroğlu, 2011: 20).

\section{Akdeniz Bölgesi}

Akdeniz Bölgesi'nde yapılan peynir çeşitleri keçi sütünden yapılmaktadır, bu bölgede genellikle tulum, hayvan derilerinden üretilen peynir çeşitleri çok fazladır. Tatlı yapımı içinde peynir çeşitleri üretilmektedir ve en ünlüsü künefe yapımında kullanılan künefe peyniridir (Bekiroğlu, 2019: 53). Bu bölgede üretilen peynir çeşitleri genellikle; Sürk, İskenderun künefe peyniri, Hatay ezme peyniri, hellim, keş peyniri, çimi tulum peyniri, Hatay dil peyniri, kuru çökelek, testi peyniri, kelle peyniri ve bez kaşar peyniri bölgenin ünlü peynirlerindendir.

Antakya Sürkü Çökeleği: Asit özelliği yüksek olan inek sütü ya da ayranın kaynatılarak içerisine zahter, biber salçası tuz ve baharatlar eklenip yoğurularak üretilmektedir. Turuncu rengi ve konik şekli ile kendine özgü bir yapısı vardır acı, ekşi ve tuzlu tatları içeren bir çökelek çeşididir (Saygılı vd., 2020: 14). 
Hatay Ezme Peyniri: Baskı peyniri olarak da yörede bilinmektedir. Olgunlaşma süresi kısa sürelidir. İnek sütünden üretilmektedir bundan dolayı da peynirin rengi beyazdır. Yapı olarak elastik ve gözeneksiz bir yapıya sahiptir. Kahvaltılarda kullanılan bir peynir çeşididir (Bekiroğlu, 2019: 55)

Keş Peyniri: Ülkemizde yoğurt ya da tereyağından üretilmektedir. Yağından ayrılıp tuzlanarak bez torbalara alınıp 1-2 gün baskılanarak olgunlaştırılır. Belirli bir şekle sahip değildir keş peyniri beyazımsı bir renktedir, yağsız kendine özgü bir kokuya sahiptir. Türkiye'nin bazı yörelerinde ham çökelek, çökelek ismiyle de bilinmektedir (Kalender ve Güzeller, 2013: 5).

Çimi Tulum Peyniri: Antalya Serik bölgesine ait bir tulum peyniridir. Çiğ keçi sütüne oğlak ya da kuzu şirdeni ve tuz ilave edilerek üretimi yapılmaktadır. Keçi tulumları içerisine peynir hava almayacak şekilde doldurulup mahzen ya da içi genellikle karlarla dolu obruklara 3 - 4 ay olgunlaştırılmak için bırakılır (Kılıç vd., 2002: 57). Keskin kokulu ve gözeneksiz bir yapıya sahiptir rengi deriye yakın bölgeler sarımtırak iken orta kısımları beyazdır (Kiraz, 2018: 15).

Hatay Dil Peyniri: Görüntüsünden dolayı bu adı almıştır. Bu peynirin yapımında çiğ koyun sütü kullanılmaktadır. Sıcak suda haşlanarak erildikten sonra peynire özgü bir şekil verilip salamura yöntemiyle olgunlaşmaya bırakılır. Yağlı tuzsuz ve kendine has kokuya tada aromaya sahip bir peynir çeşididir (Uysal, 2008: 13).

Hatay Carra Peyniri (Testi Peyniri): Keçi ya da inek sütünden üretimi yapılmaktadır. Bir kat peynir bir kat tuz ve bir kat çökelek konulur çökeleğe zahter ya da çörek otu eklenir carra adındaki testilere doldurulur testinin ağzı 3 - 4 gün sonra özel bir harçla sıvanıp kapatılır. Serin bir yerde toprağa gömülüp 3 ay olgunlaşmaya bırakılır (Aygün, 2001: 331).

Kelle Peyniri: Kahramanmaraş il ve ilçelerinde koyun sütünden üretimi yapılmaktadır. Salamura da olgunlaştırılan peynir çeşitlerindendir. Kendine has kokusu, tadı ve yapısı vardır. Genellikle yöre halkı tarafından üretimi yapılmaktadır. Haşlanarak hazırlanır ve kelle şeklindedir (Altun ve Köse, 2016: 643).

Yalvaç Küp Peyniri: Isparta'nın Yalvaç ilçesinde koyun, keçi ya da inek sütünden yapılmaktadır genellikle inek sütünden üretilmektedir. İnek sütünün içerisine maya ve tuz eklenip 1 gün bekledikten sonra elde edilen peynirin içerisine çörek otu tuz eklenip küplere doldurulur küplerin ağız kısmı özel bir harçla kapatılıp toprağa gömülür yaklaşık 1 yıl bekletilir. Kendine has bir kokusu ve acımtırak bir tadı vardır (Albay ve Şimşek, 2020: 209-212). 
Antalya Lor Peyniri: Nor peyniri olarak da bilinmektedir peynir altı suyundan elde edilmektedir. Genellikle kahvaltılarda ve böreklerde kullanılır tuzsuz sürülebilir kıvamda bir yapısı vardır (Bekiroğlu, 2019: 55).

Künefe Peyniri: Üretiminde inek sütü kullanılmaktadır mayalanıp tellemesi haşlanarak üretilir. Dil peyniri ve Sünme peyniriyle benzer özellikler gösterir tuzsuz bir peynirdir. Künefe yapımında kullanılmaktadır (Bekiroğlu, 2019: 53).

\section{Ç. Karadeniz Bölgesi}

Türkiye'deki tüm bölgeler arasında peynir çeşitliği açısından liderliği Karadeniz Bölgesi taşımaktadır. Peynirleri ahşap kovalar da olgunlaştırma yöntemi de Karadeniz Bölgesi'ne aittir. Bölge'deki peynir çeşitliği ve miktarı oldukça önemlidir. Genel olarak koyun, keçi, inek ve manda sütü kullanılmaktadır (Bekiroğlu, 2019: 75). Aho peyniri, Kolete peyniri, Gorcola peyniri, Tel peyniri, Torba peyniri, Deleme peyniri, Kaşar Tellisi gibi peynirler bölgenin ünlü peynirlerindendir.

Aho Peyniri: Trabzon Araklı ilçesinde inek sütü ve golot peyniriyle üretimi yapılmaktadır. Çok tuzlu kendine has boğazı yakan ve biberimsi bir tadı vardır. Renk olarak sarımtırak ve elma büyüklüğünde dayanaklı bir yapısı vardır (Kılıç, 2013: 45).

Kolot Peyniri: Bölgede golo, kolote, kolot, koloti olarak da bilinmektedir. Yağsız koyun ya da inek sütünden üretilmektedir. Kurun denilen fiçılarda olgunlaştırmaya bırakılır. Renk olarak sarımtırak şekil olarak pideye benzeyen kolot peyniri bölge halkının da severek yediği mıhlamanın önemli malzemelerindendir (Saygılı vd., 2020: 18).

Gorcolo Peyniri: Artvin Ardahan yörelerinde genellikle yağsız inek sütünden üretilir. Gorcolo peyniri lezzetli krem renginde bir peynirdir. Peynir özellikle yaz aylarında yapılır bunun sebebi yaz ayında peynir olgunlaşırken bir küf bırakır bu küf peynire aromatik bir tat verir peynirin bu aşamasından sonra peynire "göğermiş" de denir (Kamber ve Çelik, 2007: 5).

Telli Peyniri: Doğu Karadeniz Bölgesi’nde koyun, keçi, inek sütünden veya karışımlarından yapılmaktadır. Telli peynir yapı olarak sert bir peynirdir, orta yağlı, sarımtırak bir renge sahiptir. Erzurum Civil peyniri ve Kars Çeçil peyniri ile benzerlik göstermektedir (Öründü, 2016: 45).

Minci Peyniri: Karadeniz Bölgesi’nde “çökelek” olarak da bilinmektedir, yoğurt, süt ya da ayrandan üretilmektedir. Kuymak yapımında da kullanılır yağsız ve tuzsuz bir peynirdir kalsiyum ve protein bakımından oldukça zengindir (Aloğlu, Turhan ve Öner, 2012: 5).

Kargı Tulum Peyniri: İnek, koyun, keçi sütünden üretilir yapım aşaması farklı olan bir peynir çeşididir mayasında incir acı suyu vardır ve süt hiçbir ısıl işlem görmez iyotsuz tuz eklenerek çöktürülür. Koyun derisinde 3 ay olgunlaştırılmaya bırakılır (Kiraz, 2019: 20). 
Karın Kaymağı Peyniri: Karın kaymağı peyniri özellikle koyun sütünden üretilmektedir. Tulum peynirine benzemektedir işkembeye basılarak olgunlaştırılır yağ oranı çok yüksek bir peynir çeşididir. Genellikle Gümüşhane ve çevresinde üretimi sağlanmaktadır (Çakmakçı, Şengül ve Çağlar, 1995: 201). Yağ oranın fazla olmasından kaynaklı kendine has bir kokusu tadı ve yapısı vardır (Şengül, Erkaya ve Ceyhun, 2011: 57).

Külek Peyniri: Karadeniz Bölgesi’nin hemen hemen her ilçesinde üretilen lor ve tulum peynirinin genel adlarından birindir. Genellikle koyun sütünden üretilir son zamanlar da inek sütünden de yapılmaktadır. Külek peyniri ilkbahar ve yaz aylarında daha fazla üretimi sağlanmaktadır. Külek denilen fiçılarda peynir olgunlaşmaya bırakılır hafif tuzlu bir peynir çeşididir Aho peyniriyle benzerlik gösterir (Kamber ve Terzi, 2008: 96).

İmansız Peyniri (Tecen Peyniri- Uzayan Peynir): Genellikle Giresun-Trabzon bölgelerinde inek ya da koyun sütünün içerisine maya atılarak üretilen bir peynir çeşididir. Mayalanma işleminden sonra yoğurt kıvamı alır ve peynir suyunu bırakması için bez torbalara konularak üzerine ağırlık konur. İstenilen kıvama geldiğinde farklı biçimlerde kesilerek tuzlu suda muhafaza edilir (Ayyıldız ve Şahingöz, 2018: 403).

Minzi Kurut Peyniri: Minzi peynirinin bastırılıp kurutulmasıyla elde edilir. Minzi peynirinin tuzlanıp şekil verilerek üretildiği peynir çeşididir. 2-3 saat kurutulup olgunlaşmaya bırakılır uzun ömürlüdür (Kamber ve Terzi, 2008: 97).

Yusufeli Küflü Köy Peyniri: Artvin’inin Yusufeli ilçesinde üretimi sağlanmaktadır. Genellikle beyaz peynir veya tam yağlı süt bez torbalara aktarılır ve kuruması için güneş alan bir yerde bırakılır. Peynirin çatlamasıyla küf oluşur. Küflü bir peynir çeşididir (Kamber ve Terzi, 2008: 98).

Kadina Peyniri: Rize ilinde inek sütünden üretimi yapılmaktadır. Özellikle muhlama yapımında tercih edilir. Yapım olarak peynir yapımıyla aynıdır sadece farkı kadına adındaki fiçılarda olgunlaştırılması yapılmaktadır. Tuzlu yağsız bir peynir çeşididir (Bekiroğlu, 2019: 73).

\section{Doğu Anadolu Bölgesi}

Türkiye'nin en yüksek bölgesi olan Doğu Anadolu Bölgesi2nde hayvancılığında fazla olmasından kaynaklı kıymetli sütlerden üretilen peynirlerin yoğun olduğu bir bölgedir. Bu bölgenin en önemli peynirleri; Erzurum çivil peyniri, Kars gravyeri, Van otlu peyniri, Saçak peyniri, Şavak Tulum peyniri, Erzincan tulum peyniri.

Erzurum Civil Peyniri: Erzurum Civil peyniri meralarda özel otlarla beslenilen hayvanların sütlerinden üretilmektedir. Sütten yağ tamamen uzaklaştırılarak mayalandırılıp yoğurulur bu işlemden sonra askılara asılarak tel tel olması sağlanır. Civil peyniri beyaz renkli az tuzlu bir peynir çeşididir. Taze olarak tüketildiği gibi salamura yöntemiyle de tüketilmektedir. Coğrafi işaretle tescillenmiştir (Güzeller ve Koboyeva, 2020: 175). 
Gögermiş Peynir (Küflü Lor Peyniri): Erzurum Civil peynirinden sonra bölge halkı tarafından sevilerek tüketilen coğrafi işaretli bir peynir çeşididir. Lor peynirinin Civil peynirle birlikte tulumlara basılarak küflendirilir. Göğermiş peynir ya da küflü lor peyniri olarak da bilinmektedir (Güzeller ve Koboyeva, 2020: 176).

Kars Kaşarı: Kars ve Ardahan üretimi yapılmaktadır. Kars kaşarını diğer kaşarlardan ayıran en önemli özellik üretiminde kullanılan süttür bu sütler endemik bitkiler ve otlardan beslenen hayvanlardan alınır. Ayırt edici özelliklerinden biri ise kaşar taze iken beyaza yakın bir renktedir bir hafta sonunda ise dışında bir kabuk oluşup kaşarın renginin sarıya dönmesidir. Kabuk zaman içerisinde griye dönmektedir. Az tuzlu ve süte yakın bir tadı vardır. Altı ayda olgunlaşıp tüketime hazır hale gelir. Coğrafi işaretli peynir çeşitlerindendir (Durusoy, 2017: 20).

Kars Gravyeri: Peynirin üretiminde Zavot ırkı hayvanların sütleri kullanılmaktadır. Peynirin kabuğu altın sarısı renginde, yapısı gözenekli ve kendine ait bir kokusu vardır. Üretimi uzun süren peynir çeşitlerindendir yedi ayda tüketime hazır hale gelmektedir. 70 kg peynir tekerinin oluşumunda $700 \mathrm{~kg}$ süt kullanılır. Su, tereyağı, ekmek ile Gorcolo eritmesi yapılıp tüketilir (Güzeller ve Koboyeva, 2020: 177).

Van Otlu Peyniri: Doğu Anadolu Bölgesi ve Güneydoğu Bölgesi’nde çiğ koyun sütünden üretilmektedir. Peynirdeki lezzet ve kalite içerisine eklenen otlar, kokusu ve yapım aşamasından kaynaklanmaktadır. Gözenekli bir yapıya sahiptir ve beyazımsı bir renktedir. Kuru tuzlama ve salamura tuzlama yöntemiyle olgunlaştırılmaktadır. Coğrafi işaretli yöresel bir peynir çeşididir (Karacaoğlu, Köşker ve Yenipınar, 2014: 16).

Van Otlu Cacık Peyniri: Koyun ve keçi sütleri kaynatılarak soğutulup yoğurt mayası ile mayalandırılır. Çökelek haline gelen peynire çeşitli otlar eklenerek torbaya alınır. Otlu cacık peynirlerin bidonlara basılmasında kullanılır (Güzeller ve Koboyeva, 2020: 175).

Erzincan Tulum Peyniri: İlk coğrafi işareti alan yöresel peynirimizdir. Genellikle Karaman koyun sütünden üretimi yapılmaktadır. Tunceli, Erzincan, Elâzı̆̆ illerinde "şavak" peyniri olarak da bilinmektedir. Kemah tuzu ile bidonlara ya da tulumlara basılarak yaklaşık 1 yıl mağaralarda olgunlaştırılmaktadır. Yapısal olarak gözeneksiz, dağılmayan bir yapıya sahiptir. Kendine özgü tereyağı ve ekşimsi bir tada ve beyazımsı renge sahip yöresel bir peynir çeşididir (Akar ve Tekinşen, 2017: 220).

Türkmen Saçak Peyniri: Türkmen Saçak peyniri genellikle Kars ve Ardahan illerinde yağsız sütten üretilmektedir son zamanlarda Erzurum, Ağrı ve Iğdır'da da üretimi yapılmaktadır. Yağsı, tuzlu tel tel ayrılan uzun ömürlü yöresel bir peynir çeşididir (Kılınçlı, 2019: 15).

Şavak Tulum Peyniri: Şavak peyniri koyun sütünden üretilen orta yumuşaklıkta kendine özgü tat ve kokuya sahip yöresel bir peynir çeşididir. Genellikle Elazı̆̆g, Tunceli, Bingöl'de üretimi yapılmaktadır. Şilav adındaki maya ile mayalandırılır. Oluşan peyniri bez torbalara doldurulup sabaha kadar bekletilir ve dilimlenip tuzlu salamurada bekletilir (Güzeller ve Koboyeva, 2020: 175). 
Yaprak Peyniri: Yöresel peynirlerimizdendir genellikle Karacadağ bölgesinde üretimi sağlanır. Yaprak peyniri gri sarımtırak renginde ve çiğ koyun sütünden üretilip haşlanarak peynir hamur şeklinde aç1lır $5 \times 5 \mathrm{~cm}$ porsiyonlara ayrılarak salamura da 2-3 ay olgunlaşmaya bırakılır (Keskin, 2019).

Dövme Peyniri: Hakkâri Şemdinli ilçesinde koyun ve inek sütlerinden yapılır. Ufalanmış tuzlu ve parlak beyaz renge sahip yöresel bir peynir çeşididir (Güzeller ve Koboyeva, 2020: 176).

Motal Peyniri: Kuru tulum peyniri çeşitlerinden biri olan Motal peyniri Muş ve yöresinde çiğ koyun sütünden üretilmektedir. Motal peynirinin üretim aşamasında beyaz peynir çiğ süt ve çeçil peyniri kullanılır. Koyun ya da keçi derisine doldurularak toprağa gömülür ve 3 ay olgunlaşmaya bırakılır (Andiç, Gençcelep ve Tunçtürk, 2010: 425).

Tomas Peyniri: Tomas peyniri ülkemizde Doğu Anadolu Bölgesi’nde üretimi yapılmaktadır. Tomas peyniri yapımında koyun ve keçi sütünden yoğurt üretilir ve bu yoğurtla birlikte ayrana ısıl işlem uygulanarak çökelek elde edilir. Çökeleğe tuz, tereyağı, kaymak ve yoğurt eklenip deri tulumlara basılır. 3 ay olgunlaştırıldıktan sonra 2. kez yoğurulup tuluma basılıp tüketilir. Yörelere göre adı değişmekte olup Serto, Karın kaymağı da denmektedir. Peynirin kendine ait kokusu küfü ve rengi vardır (Korucu, 2012: 22).

Pestigen Peyniri: Pestigen peyniri Tunceli, Erzurum, Bingöl ve Elazığ illerinde üretilmektedir. Az yağlı, yumuşak kıvamlı ve kirli beyaz renge sahip bir yoğurt konsantresi çeşididir. Ekşitilerek lor haline getirilir ve suyunu bıraktıktan sonra deri tulumlara basılarak olgunlaştırılır (Güzeller ve Koboyeva, 2020: 176).

Varto Keçi Peyniri: Muş ilinin Varto ilçesinde keçi sütünden üretimi yapılmaktadır. Keçi sütü güneş altında belli bir sıcaklığa gelene kadar bekletilir ve içerisine maya ilave edilerek pıhtı haline getirilir. Bu pihtıları keten bez torbalara alarak suyu süzdürülür ve böylelikle keçi peyniri elde edilir (tr.wikipedia.org).

Herki Peyniri: Hakkâri Şemdinli ilçesine ait bir peynir çeşididir. Sütün içerisindeki yağ yayıklanarak ayrılır. Yağsız kısım mayalanır oluşan pıhtı soğuması için dinlendirilir ve yoğurt kıvamı alan pıhtı bez torbalara alınarak suyu süzülür. Yüksek bir yere alınarak peynirin sertleşmesi sağlanır. Sertleşen peynir dilimlenerek 3-4 gün bekletilir ve tüketime hazır hale getirilir (turkascihaberleri.com).

\section{E. Güneydoğu Anadolu Bölgesi}

Güneydoğu Anadolu Bölgesi peynirleri genellikle Doğu Anadolu Bölgesi ve Akdeniz Bölgesi'nden etkilenmiştir. Yazların kurak geçmesinden kaynaklı peynirlerin yapıları haşlanarak ve tuz oranı yüksek salamuralarda olgunlaştırılır. Bu bölgenin ünlü peynirleri;

Diyarbakır örgü peyniri, Gaziantep sıkma peyniri, Urfa beyaz peyniri, Mardin Tecen peyniridir 
Diyarbakır Örgü Peyniri: Türkiye'nin Güneydoğu Anadolu Bölgesi’nde genellikle bahar aylarında koyun ya da keçi ve inek sütünün karışımından yapılmaktadır. Yapım aşaması olarak kaşar peynirine benzemektedir. Beyaz parlak rengi, kendine özgü aroması ve istenildiğinde elle iplik biçiminde ayrılan Diyarbakır örgü peyniri sevilerek tüketilen peynir çeşitleri arasındadır (Saygılı vd., 2020: 17).

Gaziantep Sıkma Peyniri: Güneydoğu Anadolu Bölgesi'nin Gaziantep ilinde koyun sütünden ya da koyun ve keçi sütünün karışımından üretilmektedir. Telemesi haşlanarak yapılan peynir çeşitlerindendir. Taze olarak ya da salamurada bekletilerek tüketilir. Salamurada beklemesinden kaynaklı peynir yapı olarak sert ve çok tuzludur tüketilmeden önce sıcak suda bekletilir. Gaziantep sıkma peyniri coğrafi işaretli yöresel peynir çeşitlerindendir (Yalınız, 2019: 659).

Urfa Beyaz Peyniri: Şanlıurfa bölgesinde koyun veya keçi sütünden üretimi sağlanmaktadır. Genellikle bahar ve yaz dönemlerinde üretilir. Haşlanarak üretilen peynir çeşitlerindendir. Taze olarak tüketilebildiği gibi soğuk hava depolarında tuzlu salamurada 3 - 4 ay olgunlaştırılarak da tüketilir. Kendine özgü bir şekle ve tada sahiptir yenilmeden önce sıcak suda bekletilir (Ardıç, Yalçın ve Nizamoğlu, 2007: 90).

Siirt Otlu Peyniri: Siirt'in yöresel peynir çeşitlerinden Siirt otlu peyniri, çiğ inek sütünden ya da koyun sütünden üretilmektedir. Süt mayalandırılarak pıhtı oluşturulur bu pıhtılar bez torbalara alınır içerisine hazırlanan otlar eklenir. Baskılama işlemine alınan peynir $3-4$ saat süzülmeye bırakılır. Dilimlenerek kuru ya da salamura da tuzlanarak olgunlaştırılır (Doğan, 2012: 22).

Adıyaman Pazarcık Köy Peyniri: Yöre halkının genellikle kendi ihtiyaçlarını karşılamak için koyun sütünden üretmiş olduğu bir peynir çeşididir. Sütler kaynatılarak peynir mayası ile mayalandırılır ve mayalanan peynir cendere bezlerine alınarak baskılama yöntemi uygulanır. Peynir dilimlenerek kaynatılan peynir suyunun içine atılır. Su ılıyınca peynirler içinden alınarak tuzlanır ve bidonlara basılıp olgunlaşmaya bırakılır (yoreselpeynir.com)

Urfa Topak Peyniri: Peynire bölge halkın da kız memesi, kuzubaşı adı da verilmektedir. Genellikle çiğ koyun ve keçi sütlerinden şubat Temmuz aylarında üretilmektedir. Peynirin dayanıklılığını arttırmak için peynir iyice tuzlanır ve bidonlara basılır. Salamuralarda tuzla bekleyen peynir sertleşir ve soğuk hava depolarında temmuza kadar olgunlaştırılır (yoreselpeynir.com).

Gaziantep Tulum Peyniri: Tam yağlı sütlerden üretimi yapılmaktadır. Sütün süzme işleminden sonra 1sıtılır ve pıhtılaştırılarak içerisine maya ilave edilir oluşan pıhtı parçalanır. Keten torbalara konularak süzülür baskılama yöntemi ile süzülmeye bırakılır. Oluşan telleme ufalanır keçi veya oğlak tulumlarına basılarak olgunlaştırmaya bırakılır serin yerde muhafaza edilir (acar.coolpage.biz).

Adıyaman Basma Peyniri: Genellikle koyun sütünden üretimi yapılmaktadır. Sütler bezlerde süzdürülür, süzdürülen süt kaynatılır ve soğutulur. Süt 1lıdığında maya eklenir. 
Oluşan pıhtılar ufalanarak torbalara alınır ve peynir süzdürülme işlemine alınır. Süzülen peynirler tuzlanıp tenekeye basılarak olgunlaştırılır (acar.coolpage.biz).

Batman Kozluk Kok Peyniri: Bölge halkı tarafından koyun ve inek sütünden üretilir. Süt kaynatılır sütün üstünde kalan kısımlar alınarak bez torbalara alınır. Peynir suyunun süzdürülmesi için huni benzeri tahtadan bir yapıya alınır ve ağırlık konulur. Suyu süzülen peynir ufalanılıp 2-3 gün bekletilir. Sararan peynirler tuzlanır ve deri tulumlarda olgunlaştırılır (acar.coolpage.biz).

\section{G. İç Anadolu Bölgesi}

Kurak iklimin hâkim olduğu bu bölgede peynir üretimi genellikle koyun ve keçi sütlerinden yapılıp geleneksel yöntemle tulumlara basılarak obruklarda olgunlaştırılır (antregourmet.com) Bu bölgenin ünlü peynirleri; Divle tulum peyniri, Yozgat çanak peyniri, Küpecik peyniri, Avanos çömlek peyniri ve gödelek peyniri gibi yöresel peynir çeşitleridir.

Konya Ereğli Bez Tulum Peyniri: Konya'nın birçok ilçesinde inek veya koyun sütünden üretimi yapılmaktadır. Sütler cendere bezinden geçirilerek mayalandırılır elde edilen pıhtı bez torbalara konulur ve üzerine ağırlık konarak fazla suyunun süzülmesi sağlanır. Baskılama işleminden çıkarılan teleme ufalanarak tuzlanır. Tuzlanan peynirler eriyip şekil alması için sıcak suya konur. Eriyen peynirler bez tulumlara basılarak serin bir odada 1-2 ay olgunlaştırılmaya bırakılır (Çalım, 2007: 22).

Konya Cihanbeyli Küflü Peyniri: Konya’nın Cihanbeyli, Karapınar, Ereğli gibi koyun üretiminin yoğun olduğu bölgelerde üretimi yapılmaktadır. Yağı alınmış koyun sütünden üretilen Cihanbeyli küflü peyniri yöresel bir peynir çeşididir. Yağının alınmasından kaynaklı doğal küflenen peynir aflatoksin oluşumunu engelliyor (eregli.bel.tr).

Sivas Küp Peyniri: Sivas ve ilçelerinde tam yağlı ya da az yağlı inek sütünden üretilmektedir. Peynir mayası ilave edilen ve kendine has lezzeti ve aromatik tadı olan yöresel bir peynir çeşididir. Elde edilen pıhtı küçük kalıplar halinde kesilerek tuzlanır ve küplere yerleştirilir. Küpün boş kalan yerlerine çörek otu, lor ve üretimi sağlanan peynir ufalanarak doldurulur. Doldurulan peynir ağzı bezle kapatılarak yarısı ya da tamamı toprağa gömülerek olgunlaştırılır (Ergin ve Koca, 2019: 5).

Divle Tulum Peyniri: Divle tulum peyniri adını konulduğu obruktan almıştır. Genellikle koyun sütünden ya da koyun ve inek sütünün karıştırılarak kullanılmasıyla üretilmektedir. Hazırlanan peynir ufanılıp tuzlanarak koyun keçi tulumlarına basılır 1 hafta evde bekletilip daha sonra olgunlaştırılmak için obruğa bırakılır. Olgunlaşan peynir kendine ait bir küf bırakır. Küflendirilerek olgunlaştırılan coğrafi işaretli bir peynir çeşididir (Morul,2011: 25).

Yozgat Çanak Peyniri: Coğrafi işaretli peynir çeşitlerimizdendir. Yozgat ve ilçelerinden küçükbaş hayvanların sütlerinden üretimi yapılmaktadır. Yarım yağlı ya da az olgunlaşmış peynir çanakların içine basılarak olgunlaştırılmak için kuma gömülür. 
Gömülen kumun nemli ve rutubetli olması olgunlaştırma aşamasında önemlidir (Saygılı vd., 2020: 16).

Avanos Çömlek Peyniri: Genellikle koyun ve inek peynirlerinin suya konularak acısı çıkartılıp üretilmektedir. Süzülen peynirler parçalanarak tuzlanarak çömleklere basılır. Çömleğin ağzının hava almaması için çömlek çamurla veya hamurla kapatılır. Kilerde hazırlanan dere kumuna gömülerek 3-4 ay olgunlaştırılır (Güldemir ve Işık, 2011: 5).

Gödelek- Niğde Küp Peyniri: Adını peynirlerin içine basıldığı çömlekten almaktadır. İnek, koyun ve keçi sütünün mayalandırılmasıyla üretilir. Elde edilen peynir küplere basılarak kuma gömülerek olgunlaştırılır (Okur, 2010: 16).

Kayseri Çömlek Peyniri: Kayseri ve Kayseri’nin belli yörelerinde taze süzülmüş peynirden üretilir. Soğuk suda bekletilen peynir haşlanarak ufalanıp tuzlanır, çörek otu da isteğe bağlı eklenir. Boşluk olmayacak şekilde küplere basılır. Küpün ağzı iç yağı ile kapatılır. Olgunlaştırılmak için serin bir ortamda kuma gömülür (Özgören ve Seçkin, 2012: 55).

Konya Küflü Peyniri: Konya ili ve bölgelerinde üretilmektedir süt mayalanıp süzdürülür oluşan pıhtı bezlere doldurulur üzerine ağırlık konarak peynir suyu süzdürülür, oluşan teleme koyun keçi tulumlarına basılır tulum delinerek üzerine ağırlık konup bir hafta bekletilir. Süzülen peynir 3-4 ay olgunlaştırılmak için serin yerde muhafaza edilir (Özgören ve Seçkin, 2012: 56).

Gölbaşı Tulum Peyniri: Ankara Gölbaşı ilçesinde inek koyun ya da keçi sütlerinden üretilmektedir. Mayalanan peynirden oluşan pıhtı bez torbalara doldurulur ve suyunun süzülmesi için baskı uygulanır. Teleme kesilerek salamura konup 2-3 ay olgunlaştırılır. Olgunlaşan peynir rendelenerek kuzu tulumuna basılır. Süzülen peynir ikince kez yağ durumuna bakılıp içerisine krema eklenerek tekrar tuluma basılır ve olgunlaşması için 22,5 ay serin yerde muhafaza edilir (Gün, 2012).

Kargı Tulum Peyniri: Çorum'un Kargı ilçesinde koyun, keçi, inek, manda sütünden üretilmektedir. Süt mayalanır oluşan pıhtı bez torbalara aktarılıp baskı uygulanarak süzdürülür. Süzülen peynir geniş bir leğene alınarak tuzlanıp bez torbalara alınarak baskı uygulanır. $\mathrm{Bu}$ işlem bir ay devam eder istenilen kıvama geldiğinde kıvırcık ırkı koyun tuluma basılarak olgunlaştırılmak için serin yerde muhafaza edilir (Gün, 2012: 17).

Çepni Tulum Peyniri: Konya il ve yörelerinde keçi sütünden üretimi sağlanır. Tam yağlı keçi sütü mayalandırılır oluşan pıhtı kırılır ve bez torbalarda peynir suyu süzdürülür. İstenilen kıvama geldiğinde tekrar parçalanır ve başka bir tuluma aktarılır. Aktarılan tulumun ağzı dikilir 3-4 ay mağaralarda olgunlaştırmaya bırakılır (Gün, 2012: 17).

Karaman Ermenek Tulum Peyniri: Karaman bölgesinde tam yağlı koyun sütünden üretimi sağlanmaktadır. Elde edilen pıhtı tuzlanarak içerisine çörek otu eklenir ve olgunlaştırılmak için deri tulumlara basılır (Gün, 2012: 19). 


\section{Ğ. Kuzey Kıbrıs Türk Cumhuriyeti}

Hellim Peyniri: Kıbrıs peyniri olarak dilimize geçmiştir genel olarak koyun ve keçi sütünden üretimi yapılmaktadır son zamanlarda inek sütünden de yapımına başlanılmıştır. İnek sütünden üretilen hellim peynirinin rengi beyaz iken koyun ve keçi sütünden üretilen peynirler sarımtıraktır. Hellim peyniri yapı olarak yarı sert bir yapıdadır. Salamura tekniği ile tenekelerde olgunlaştırılmıştır. Hellim peyniri kızartılarak da yemeklerde kahvaltılar da tüketilmektedir (Erbay, Koca ve Üçüncü, 2010: 5).

\section{Endüstriyel Peynirler}

Ülkemizde peynir çeşitliliği bakımından en çok üretilen endüstriyel peynirler, beyaz peynir, kaşar peyniri, tulum peynirdir (Tarakçı vd., 2015: 56). Türkiye'deki peynir çeşitlerinin tüketimdeki payının \% 85 - 89'unu beyaz salamura, kaşar ve tulum peynirleri, geri kalan \% 11-15'ini de çeşitli yöresel peynirler oluşturmaktadır (Tekinşen ve Nizamoğlu, 2003: 154). Bunlara ek olarak çeşitli otlu peynirler, çökelekler ve yöresel peynirler endüstriyel ve butik olarak üretilmektedir.

İnek peyniri üretimi 2020 yılında 53.675 ton ile bir önceki yılın aynı ayına göre yüzde 10 artmıştır. Koyun, keçi, manda ve karışık sütlerden elde edilen peynir çeşitleri ise 3,422 ton ile bir önceki yılın aynı ayına göre yüzde 26,7 artmıştır. Son üç yılın peynir üretim miktarları karşılaştırıldığında, her yıl belli oranlarda artışlar görülmektedir. Bunun sebepleri, her geçen yıl ürün talebinin artışı, peynir üretiminde teknolojinin gelişmesi ve salgın döneminde gıda maddelerinde oluşan talep artışı söylenebilir. TUİK verileri incelendiğinde, 2021 yılında 59.834 ton peynir üretilmiştir. TUİK'ten ulaşılan verilere göre son 10 yılın en yüksek üretim miktarı elde edilmiştir (TUİK, 2021).

\section{A. Beyaz Peynir}

Üretiminde genellikle koyun, keçi ve inek sütü kullanılmaktadır ve genellikle bu sütler çiğ ya da pastörize olarak kullanılmaktadır. Süt belli bir sıcaklığa getirildiğinde şirden mayası eklenerek pıhtılaştırılır ve cendere bezlerine alınarak baskı uygulanıp porsiyonlara bölünür ve hazırlanmış olan salamurada bekletilerek olgunlaştırılıp tüketime uygun hale getirilir. Sütün hangi cins hayvandan temin edildiğine ve peynirin yapısına göre farklı beyaz peynirler üretilebilmektedir (Tablo 1).

Tablo 1. Türkiye'de Üretilen Bazı Beyaz Peynir Çeşitlerinin Farklılıkları

\begin{tabular}{|c|c|c|c|c|c|c|}
\hline & & & Olgunlaştırma & & & \\
\hline Bölge & Peynir & Süt & Yöntemi & Yapı & Mayalama & Haşlama \\
\hline Marmara & $\begin{array}{l}\text { Edirne } \\
\text { Peyniri }\end{array}$ & Çiğ/ Pastörize & Salamura & Gözenekli & Şirden & \\
\hline Ege & $\begin{array}{l}\text { Ezine } \\
\text { Peyniri }\end{array}$ & Koyun/ Keçi & Salamura & Gözenekli & Şirden & \\
\hline İç Anadolu & $\begin{array}{l}\text { Konya } \\
\text { Keçi } \\
\text { peyniri }\end{array}$ & Keçi & Salamura & Gözeneksiz & $\begin{array}{l}\text { Peynir } \\
\text { Mayas1 }\end{array}$ & \\
\hline
\end{tabular}




\begin{tabular}{lllllll}
\hline & Hellim & Keçi/ Koyun/ & & & & Pıhtısı \\
Kıbrıs & Peyniri & İnek & Salamura & Gözeneksiz & Taze Süt & Hașlanır \\
\hline
\end{tabular}

\section{B. Kaşar Peyniri}

Kaşar peyniri çok sık tüketilen sert peynirlerdendir. Genellikle koyun sütünden üretilmektedir. Pihtısı haşlanarak ya da telleme yöntemi kullanılır. Üretim tekniği olarak beyaz peynirle benzer bir özellik göstermektedir beyaz peynir üretiminden fark1 tellemenin fermantasyona bırakılmasıdır. Geleneksel üretim tekniğinde asitlik gelişimi uygun hale geldiğinde "sicim çekme" veya "yaprak açma" işlemleriyle belirlenir. Bu işlem sonucunda pütürsüz ve kopmayan bir yapıya geldiğinde haşlanabilir. İstenilen asit derecesine geldiğinde telleme dilimlenir ince ince kesilerek $\% 3-5$ oranında tuz bulunan haşlama suyuna atılarak hamur hali alır oluşan bu hamur yoğurularak göbek bağlanıp kalıplara yerleştirilir. Kaşar peyniri hazır hale geldiğinde çuval içinde soğuk hava depolarında ya da mağaralarda bekletilip eskitilir (Özkaya vd., 2008: 5). Üretim yöntemine göre Türkiye'de üretilen farklı kaşar peynirler Tablo 2'de verilmiş̧ir.

Tablo 2. Türkiye'de Üretilen Bazı Kașar Peynir Ceșitlerinin Farklılıkları

\begin{tabular}{|c|c|c|c|c|c|c|c|}
\hline Bölge & Peynir & Süt & $\begin{array}{l}\text { Olgunlaştır } \\
\text { ma Yöntemi }\end{array}$ & Yapı & $\begin{array}{l}\text { Mayalam } \\
\text { a }\end{array}$ & Haşlama & Renk \\
\hline $\begin{array}{l}\text { Doğu } \\
\text { Anadolu }\end{array}$ & $\begin{array}{l}\text { Kars } \\
\text { Kaşar } \\
\text { Peyniri }\end{array}$ & $\begin{array}{l}\text { İnek/ } \\
\text { Koyu } \\
\text { n/ } \\
\text { Keçi }\end{array}$ & Soğuk Oda & Elastik & Şirden & $\begin{array}{l}\text { Pıhtısı } \\
\text { Haşlanar } \\
\text { ak }\end{array}$ & Sar1 \\
\hline $\begin{array}{l}\text { Marmar } \\
\text { a }\end{array}$ & $\begin{array}{l}\text { Kırıkkal } \\
\text { e Kaşar } \\
\text { Peyniri }\end{array}$ & $\begin{array}{l}\text { İnek/ } \\
\text { Koyu } \\
\text { n/ } \\
\text { Keçi }\end{array}$ & Soğuk Oda & Elastik & Şirden & $\begin{array}{l}\text { Pıhtısı } \\
\text { Haşlanar } \\
\text { ak }\end{array}$ & $\begin{array}{l}\text { Limo } \\
\mathrm{n} \\
\text { Saris1 }\end{array}$ \\
\hline $\begin{array}{l}\text { Karaden } \\
\text { iz }\end{array}$ & $\begin{array}{l}\text { Trabzon } \\
\text { Kadırga } \\
\text { Kaşar } \\
\text { Peyniri }\end{array}$ & $\begin{array}{l}\text { İnek/ } \\
\text { Koyu } \\
\mathrm{n}\end{array}$ & Soğuk Oda & Elastik & $\begin{array}{l}\text { Peynir } \\
\text { Mayas1 }\end{array}$ & $\begin{array}{l}\text { Pıhtısı } \\
\text { Haşlanar } \\
\text { ak }\end{array}$ & $\begin{array}{l}\text { Açık } \\
\text { Sarı }\end{array}$ \\
\hline $\begin{array}{l}\text { Karaden } \\
\text { iz }\end{array}$ & $\begin{array}{l}\text { Tonya } \\
\text { Kaşar } \\
\text { Peyniri }\end{array}$ & İnek & Soğuk Oda & Elastik & $\begin{array}{l}\text { Peynir } \\
\text { Mayas1 }\end{array}$ & $\begin{array}{l}\text { Pihtıs1 } \\
\text { Haşlanar } \\
\text { ak }\end{array}$ & Sar1 \\
\hline $\begin{array}{l}\text { Doğu } \\
\text { Anadolu }\end{array}$ & $\begin{array}{l}\text { Muş } \\
\text { Kaşar } \\
\text { Peyniri }\end{array}$ & $\begin{array}{l}\text { İnek/ } \\
\text { Keçi }\end{array}$ & Soğuk Oda & $\begin{array}{l}\text { Yumuşa } \\
\mathrm{k}\end{array}$ & Şirden & & $\begin{array}{l}\text { Koyu } \\
\text { Sar1 }\end{array}$ \\
\hline $\begin{array}{l}\text { Doğu } \\
\text { Anadolu }\end{array}$ & $\begin{array}{l}\text { Kars } \\
\text { Gravyer } \\
\mathrm{i} \\
\end{array}$ & İnek & Salamura & $\begin{array}{l}\text { Sert ve } \\
\text { Gözenek } \\
\text { li }\end{array}$ & $\begin{array}{l}\text { Peynir } \\
\text { Mayası/Es } \\
\text { ki Gravyer }\end{array}$ & $\begin{array}{l}\text { Pihtısı } \\
\text { Haşlanar } \\
\text { ak }\end{array}$ & $\begin{array}{l}\text { Açık } \\
\text { Sarı }\end{array}$ \\
\hline
\end{tabular}

\section{Tulum Peyniri}

Tulum peyniri hemen tüketilmeyen belli bir olgunlaşmaya ulaşması gereken bir peynir çeşididir. Eskilerden gelen bir özellikle peynirlerin daha uzun ömürlü olması için 
tulumlara basılara gömülür ve peynirin ömrü uzatılır. Genellikle üretimin de inek, yağlı ya da yağsız koyun ve keçi sütü kullanılır. Üretiminde pastörize ya da çiğ süt kullanılarak mayalama işlemi yapılır. Oluşan telleme elle ya da bir bıçak yardımıyla küçük parçalara bölünerek tulum, bidon, teneke kutular içine konularak toprakta, mağarada, obruklarda $2-3$ ay olgunlaşmaya bırakılır (Özkaya ve Akgün, 2008: 38). Çeşitli tulum peynirlerin üretim ve depolama şekilleri Tablo 3 'te verilmiştir.

Tablo 3. Türkiye'de Üretilen Bazı Tulum Peynir Çeşitlerinin Farklılıkları

\begin{tabular}{llllll}
\hline Peynir & Süt & $\begin{array}{l}\text { Olgunlaşma } \\
\text { Süresi }\end{array}$ & Depolama & $\begin{array}{l}\text { Ambalaj } \\
\text { Tipi }\end{array}$ & Mayalama \\
\hline $\begin{array}{l}\text { Erzincan } \\
\text { Tulum Peyniri }\end{array}$ & Koyun & 2-3 ay & Soğuk Hava & Bidon/Deri & Şirden \\
\hline $\begin{array}{l}\text { Afyon Tulum } \\
\text { Peyniri }\end{array}$ & $\begin{array}{l}\text { Koyun/ } \\
\text { Keç/İnek }\end{array}$ & 6-18 ay & Mağara & Deri/Tulum & Çiğ Süt \\
\hline $\begin{array}{l}\text { Şavak Tulum } \\
\text { Peyniri }\end{array}$ & Koyun/Keçi & 2-3 ay & $\begin{array}{l}\text { Mağara/ } \\
\text { Soğuk Hava }\end{array}$ & Tulum/Bidon & Çiğ Süt \\
\hline $\begin{array}{l}\text { Çimi Tulum } \\
\text { Peyniri }\end{array}$ & Keçi & 3-4 ay & Mahzen/Obruk & Tulum & $\begin{array}{l}\text { Oğlak } \\
\text { Şirdeni }\end{array}$ \\
\hline $\begin{array}{l}\text { İzmir Tulum } \\
\text { Peyniri }\end{array}$ & Koyun & 6 ay & Mahzen/Mağara & Tulum & Şişe Mayasi \\
\hline $\begin{array}{l}\text { Sivas Küp } \\
\text { Tulum Peyniri }\end{array}$ & İnek & 3 ay & Toprak & Küp/Bidon & Şirden \\
\hline $\begin{array}{l}\text { Divle Obruk } \\
\text { Tulum Peyniri }\end{array}$ & Koyun/Keçi & 5-6 ay & Mağara & Tulum & Şirden \\
\hline
\end{tabular}

\section{Yöntem}

Çalışmada nitel araştırma yaklaşımı kapsamındaki durum çalışması yaklaşımı deseni kullanılmıştır. Analizi yapılan veriler daha önce yapılan çalışmalardan ve söz konusu peynirin üretimini veya denetimini gerçekleştiren kurum ve işletmelerden sağlanmıştır. Verilerin analizlerinde elde edilen veriler betimsel analiz tekniği ile değerlendirilmiştir. Betimsel analizde amaç elde edilen verilerin düzenlenmesi ve yorumlanması araştırma sonuçlarının anlaşılır şekilde sunulmasıdır (Şahin ve Gürbüz, 2014: 413). Bu amaçla Türkiye'deki 7 farklı coğrafi bölgedeki tüm şehirlerde (81) üretilen geleneksel peynirler araştırılmıştır. Türkiye'de üretilen peynirlerin tamamının besin değerlerinin belirlenmemiş olması araştırmanın sınırlılığ olarak belirlenmiştir. Araştırmada kullanılan veriler 01.05.2021 - 25.06.2021 tarihleri arasında literatür taraması ve kayıt dışı sözlü görüşmeler ile elde edilmiştir. Ardından TÜİK'in verileri doğrultusunda, Türkiye'de en çok üretilen endüstriyel peynirler ile bu peynirlerin üretim teknikleri ve besin öğelerindeki farklılıklar belirlenmiştir. Söz konusu farklılıklar doğrultusunda kategoriler oluşturularak peynirlerin besin öğeleri sayısallaştırılmıştır. Sayısallaştırılan besin değerleri SPSS programı kullanılarak analiz edilmiştir. Elde edilen besin 
değerlerine ilişkin verilerle betimleyici analizler yapılmıştır. Bu doğrultuda frekans analizi yapılmış ve çapraz tablolar oluşturulmuştur. Söz konusu analizlerin sonucunda değerlendirmeler yapılmıştır.

\section{Bulgular}

Türkiye'de yedi coğrafi bölgenin farklı özellikleri ve süt inekçiliğinin farklı şekillerde yapılıyor olması bölgeden bölgeye ve ilden ile peynirlerin çeşitlenmesini sağlamıştır. Çalışmadaki bulgular değerlendirildiğinde Marmara Bölgesi'nde 7, Ege Bölgesi'nde 7, Akdeniz Bölgesi'nde 10, Karadeniz Bölgesi'nde 12, Doğu Anadolu Bölgesi'nde 16, Güney Doğu Anadolu Bölgesi'nde 9, İç Anadolu Bölgesi’nde 13, Kuzey Kıbrıs Türk Cumhuriyeti'nde 1 olmak üzere toplam 75 çeşit peynir belirlenmiştir (Şekil 1). Bu peynir çeşitlerinin bir kısmı endüstriyel olarak üretilmekte olup sadece 25 adet peynir mahreç ve menşei coğrafi işaret tescili almıştır (ci.turkpatent.gov.tr). Özet kısminda da belirtildiği üzere söz konusu peynirlerden sadece 21 tanesinin analizleri yapılmış ve besin değerleri tespit edilmiştir. Çalışma söz konusu peynirlerin analiz sonuçları üzerinden yürütülmüştür.

Tablo 4. Türkiye'de Üretilen Bazı Yöresel Peynirlerin Besin Değerlerinin Karşılaştırılması (100g)

\begin{tabular}{|c|c|c|c|c|c|c|}
\hline Peynir & $\begin{array}{c}\text { Bulunduğu } \\
\text { Coğrafi Bölge }\end{array}$ & $\begin{array}{l}\text { Enerji } \\
\text { Değeri }\end{array}$ & Yăg & $\begin{array}{c}\text { Doymuş } \\
\text { Yağ }\end{array}$ & Protein & Tuz \\
\hline $\begin{array}{l}\text { Antep Sikma } \\
\text { Peyniri }\end{array}$ & $\begin{array}{l}\text { Güneydoğu } \\
\text { Anadolu }\end{array}$ & $392 \mathrm{Kcal}$ & $31 \mathrm{~g}$ & $19 \mathrm{~g}$ & $24 \mathrm{~g}$ & $0 \mathrm{~g}$ \\
\hline Örgü Peyniri & $\begin{array}{l}\text { Güneydoğu } \\
\text { Anadolu }\end{array}$ & $286 \mathrm{Kcal}$ & $20 \mathrm{~g}$ & $0 \mathrm{~g}$ & $25 \mathrm{~g}$ & $0 \mathrm{~g}$ \\
\hline $\begin{array}{l}\text { Edirne Beyaz } \\
\text { Peyniri }\end{array}$ & Marmara & $309 \mathrm{Kcal}$ & $23,6 \mathrm{~g}$ & $0 \mathrm{~g}$ & $16,1 \mathrm{~g}$ & $0 \mathrm{~g}$ \\
\hline $\begin{array}{l}\text { Erzincan Tulum } \\
\text { Peyniri }\end{array}$ & Doğu Anadolu & $365 \mathrm{Kcal}$ & $29,2 \mathrm{~g}$ & $20,37 \mathrm{~g}$ & $21,9 \mathrm{~g}$ & $2,36 \mathrm{~g}$ \\
\hline Ezine Peyniri & Marmara & $\begin{array}{l}343,5 \\
\text { Kcal } \\
\end{array}$ & $31 \mathrm{~g}$ & $19,7 \mathrm{~g}$ & $15,5 \mathrm{~g}$ & $3,2 \mathrm{~g}$ \\
\hline $\begin{array}{l}\text { Divle Obruğu } \\
\text { Peyniri }\end{array}$ & İç Anadolu & $351 \mathrm{Kcal}$ & $24,8 \mathrm{~g}$ & $17,3 \mathrm{~g}$ & $31,5 \mathrm{~g}$ & $3,5 \mathrm{~g}$ \\
\hline Kars Kaşarı & Doğu Anadolu & 377 Kcal & $29,4 \mathrm{~g}$ & $0 \mathrm{~g}$ & $27,6 \mathrm{~g}$ & $0,5 \mathrm{~g}$ \\
\hline $\begin{array}{l}\text { Kars Gravyer } \\
\text { Peyniri }\end{array}$ & Doğu Anadolu & $413 \mathrm{Kcal}$ & $32,34 \mathrm{~g}$ & $18,91 \mathrm{~g}$ & $29,81 \mathrm{~g}$ & $0 \mathrm{~g}$ \\
\hline $\begin{array}{l}\text { Trakya Eski } \\
\text { Kaşar Peyniri }\end{array}$ & Marmara & $424 \mathrm{Kcal}$ & $33,5 \mathrm{~g}$ & $22,27 \mathrm{~g}$ & $27,6 \mathrm{~g}$ & $2,91 \mathrm{~g}$ \\
\hline $\begin{array}{l}\text { Antakya Sürk } \\
\text { Peyniri }\end{array}$ & Akdeniz & $176 \mathrm{Kcal}$ & $4,8 \mathrm{~g}$ & $2,82 \mathrm{~g}$ & $29,9 \mathrm{~g}$ & $2,47 \mathrm{~g}$ \\
\hline $\begin{array}{l}\text { Van Otlu } \\
\text { Peyniri } \\
\end{array}$ & Doğu Anadolu & $323 \mathrm{Kcal}$ & $26 \mathrm{~g}$ & $19 \mathrm{~g}$ & $18 \mathrm{~g}$ & $0 \mathrm{~g}$ \\
\hline $\begin{array}{l}\text { Kirli Hanım } \\
\text { Peyniri }\end{array}$ & Marmara & $\begin{array}{c}242,18 \\
\text { Kcal }\end{array}$ & $33,33 \mathrm{~g}$ & $0 \mathrm{~g}$ & $\begin{array}{c}30,52 \\
\mathrm{~g}\end{array}$ & $7,07 \mathrm{~g}$ \\
\hline Mihaliç Peyniri & Marmara & $335 \mathrm{Kcal}$ & $24,4 \mathrm{~g}$ & $15,76 \mathrm{~g}$ & $26,2 \mathrm{~g}$ & $2,95 \mathrm{~g}$ \\
\hline
\end{tabular}




\begin{tabular}{lcccccc}
\hline Kolot Peyniri & Karadeniz & $253 \mathrm{Kcal}$ & $15,3 \mathrm{~g}$ & $10,05 \mathrm{~g}$ & $25,6 \mathrm{~g}$ & $1,68 \mathrm{~g}$ \\
\hline Sepet Peyniri & Marmara & $376 \mathrm{Kcal}$ & $56,6 \mathrm{~g}$ & $31,55 \mathrm{~g}$ & $26,5 \mathrm{~g}$ & $4,5 \mathrm{~g}$ \\
\hline $\begin{array}{l}\text { İzmir Tulum } \\
\text { Peyniri }\end{array}$ & Ege & $346 \mathrm{Kcal}$ & $28,5 \mathrm{~g}$ & $16,8 \mathrm{~g}$ & $22 \mathrm{~g}$ & $1,7 \mathrm{~g}$ \\
\hline $\begin{array}{l}\text { Karg1 Tulum } \\
\text { Peyniri }\end{array}$ & İç Anadolu & $409 \mathrm{Kcal}$ & $52,6 \mathrm{~g}$ & $25,9 \mathrm{~g}$ & $26,74 \mathrm{~g}$ & $4,8 \mathrm{~g}$ \\
\hline $\begin{array}{l}\text { Erzurum Civil } \\
\text { Peyniri }\end{array}$ & Doğu Anadolu & $146 \mathrm{Kcal}$ & $0,7 \mathrm{~g}$ & $0,37 \mathrm{~g}$ & $32,5 \mathrm{~g}$ & $0,97 \mathrm{~g}$ \\
\hline $\begin{array}{l}\text { Dil Peyniri } \\
\text { İsli Çerkes }\end{array}$ & Marmara & $323 \mathrm{Kcal}$ & $25 \mathrm{~g}$ & $17,11 \mathrm{~g}$ & $23 \mathrm{~g}$ & $1,1 \mathrm{~g}$ \\
\hline $\begin{array}{l}\text { Peyniri } \\
\text { Abaza Peyniri }\end{array}$ & Marmara & $350 \mathrm{Kcal}$ & $27,1 \mathrm{~g}$ & $18,08 \mathrm{~g}$ & $23,7 \mathrm{~g}$ & $0,5 \mathrm{~g}$ \\
\hline
\end{tabular}

Çalışma kapsamında ulaşılan besin değeri analizi yapılmış peynirlere iliş̧in verilerle öncelikle frekans analizi yapılmıștır. Yapılan frekans analizi sonucunda, en çok peynir çeşidine sahip bölgenin 9 peynir çeşidi $(\% 40,9)$ ile Marmara Bölgesi olduğu tespit edilmiştir. Marmara Bölgesi'ni 5 peynir çeşidi $(22,7)$ ile Doğu Anadolu Bölgesi takip etmektedir. İç Anadolu ve Güneydoğu Anadolu bölgeleri 2'şer peynirle Doğu Anadolu Bölgesi'ni takip etmişlerdir. Ege, Akdeniz ve Karadeniz bölgelerinden ise 1'er peynir çalışmada analizi yapılan peynirler arasındadır.

Diğer taraftan besin değerlerine ulaşılabilen ve analize dahil edilen peynirlerden 12 tanesinin yarım yağlı olduğu belirlenmiştir. Söz konusu yarım yağlı peynirler tüm peynirlerin \%57,1'ini oluşturmaktadır. Toplam peynir sayısı içerisinde yağsız peynir sayısı 2 adettir. Aynı şekilde tam yağlı peynir sayısı da 2 adettir. Az yağlı peynir sayısı ise 5 olarak tespit edilmiştir. Araştırma kapsamındaki peynirlerin tuz oranlarına ilişkin yapılan analiz sonucunda, 8 peynirin düşük, 9 peynirin yüksek, 3 peynirin orta ve 1 peynirin çok yüksek tuz oranına sahip olduğu tespit edilmiştir. Ayrıca yapılan analiz sonucunda, tüm peynirler içerisinde protein oranı orta düzeyde olan 15 adet peynir olduğu belirlenmiştir. Düşük ve yüksek protein oranına sahip peynirlerin 3'er adet olduğu belirlenmiş̧tir. Doymuş yağ oranlarına göre yapılan frekans analizi sonucunda ise 11 adet peynirin orta düzeyde doymuş yağa sahip olduğu belirlenmiş̧ir. Düşük düzeyde doymuş yağa sahip peynir sayısı 6 , yüksek doymuş yağa sahip peynir sayısı ise 4 olarak tespit edilmiştir.

Tablo 5. Frekans Analizi Sonuçları

\begin{tabular}{|c|c|c|c|c|c|}
\hline $\begin{array}{l}\text { Bölgelere Göre Peynir } \\
\text { Sayısı }\end{array}$ & $N$ & $\%$ & $\begin{array}{l}\text { Yă̆ Oranlarına Göre } \\
\text { Dă̆ılım }\end{array}$ & $N$ & $\%$ \\
\hline Doğu Anadolu & 5 & 23,8 & Yağs1z & 2 & 9,5 \\
\hline Güneydoğu Anadolu & 2 & 9,5 & Az Yağlı & 5 & 23,8 \\
\hline İç Anadolu & 2 & 9,5 & Yarım Yağlı & 12 & 57,1 \\
\hline Ege & 1 & 4,8 & Tam Yağlı & 2 & 9,5 \\
\hline Marmara & 9 & 42,9 & Toplam & 21 & 100 \\
\hline
\end{tabular}




\begin{tabular}{|c|c|c|c|c|c|}
\hline Akdeniz & 1 & 4,8 & $\begin{array}{l}\text { Protein Oranlarına Göre } \\
\text { Dağılım }\end{array}$ & $N$ & $\%$ \\
\hline Karadeniz & 1 & 4,8 & Düşük & 3 & 14,3 \\
\hline Toplam & 21 & 100 & Orta & 15 & 71,4 \\
\hline Tuz Oranlarına Göre & $N$ & $\%$ & Yüksek & 3 & 14,3 \\
\hline Dağılım & & & Toplam & 21 & 100 \\
\hline Düşük & 8 & 38,1 & $\begin{array}{l}\text { Doymuş Yă̆ Oranlarına } \\
\text { Göre Dağılım }\end{array}$ & $\mathbf{N}$ & $\%$ \\
\hline Orta & 3 & 14,3 & Düşük & 6 & 28,6 \\
\hline Yüksek & 9 & 42,9 & Orta & 11 & 52,4 \\
\hline Çok Yüksek & 1 & 4,8 & Yüksek & 4 & 19,0 \\
\hline Toplam & 21 & 100 & Toplam & 21 & 100 \\
\hline
\end{tabular}

Frekans analizi sonrasında peynir rotaları ile ilgili değerlendirme yapabilmek için bölgelerin bağımsız değişken olarak belirlenmesine karar verilmiştir. Bölgelere göre peynirlerin besin değerlerinin değerlendirilmesine yönelik olarak çapraz tablolar oluşturulmuştur. Bunun nedeni gastronomi turizmine katılacak kişilere, çalışma kapsamında yer alan peynirlerin besin değerlerinin bölgelere göre değişip değişmediğini gösterebilmektir. Böylelikle söz konusu turistler peynir rotalarını belirlerken bölgelerin peynirlerinin besin değerleri hakkında fikir sahibi olabileceklerdir.

Çalışma kapsamındaki peynirlerin bölgelere yağ oranlarına ilişkin yapılan analiz sonucunda, Türkiye'de genel olarak yarım yağlı peynirlerin oranının toplam peynirlerin \%57,1'ini kapsadığı tespit edilmiştir. Çalışma kapsamında yer alan ve besin değerleri analiz edilmiş peynirlerin yarısından fazlası yarım yağlı peynir kategorisinde yer almaktadır. Ayrıca Marmara Bölgesi 6 adet yarım yağlı peynire sahiptir. Doğu Anadolu Bölgesi ise 4 adet yarım yağlı peynire sahiptir. Tam yağlı peynir 2 adettir. Söz konusu peynirlerin biri İç Anadolu diğeri ise Marmara bölgelerinde üretilmektedir. Çalı̧̧ma kapsamındaki peynirlerin $\% 23,8^{\prime} i$ ise az yağlı peynir kategorisindedir.

Tablo 6. Bölgelere Göre Peynirlerin Yağ Oranlarına İlişkin Çapraz Tablo

\begin{tabular}{|l|l|l|l|l|l|}
\hline \multirow{2}{*}{ Bölgeler } & \multicolumn{4}{|c|}{ Yă̆ Oranı } & \multirow{2}{*}{ Toplam } \\
\cline { 2 - 5 } & Yağsız & $\begin{array}{l}\text { Az } \\
\text { Yağlı }\end{array}$ & $\begin{array}{l}\text { Yarım } \\
\text { Yağlı }\end{array}$ & $\begin{array}{l}\text { Tam } \\
\text { Yağlı }\end{array}$ & \\
\hline Doğu Anadolu & 1 & 0 & 4 & 0 & 5 \\
Güneydoğu Anadolu & 0 & 1 & 1 & 0 & 2 \\
İç Anadolu & 0 & 1 & 0 & 1 & 2 \\
Ege & 0 & 0 & 1 & 0 & 1 \\
Marmara & 0 & 2 & 6 & 1 & 9 \\
Akdeniz & 1 & 0 & 0 & 0 & 1 \\
Karadeniz & 0 & 1 & 0 & 0 & 1 \\
\cline { 2 - 5 }
\end{tabular}




\begin{tabular}{l|l|l|l|l} 
Toplam & 2 & 5 & 12 & 2 \\
\hline
\end{tabular}

Çalışmada ele alınan peynirlerin ait oldukları bölgelere göre protein düzeylerine ilişkin analiz sonuçlarına Tablo 7 'de yer verilmiştir. Sonuçlara göre Türkiye genelinde peynirlerin $\% 71,4$ 'ünün orta düzeyde protein değerine sahip oldukları tespit edilmiştir. Çalışma kapsamında bulunan peynirlerin 15 tanesinin orta düzeyde protein değerine sahip olduğu görülmüştür. Protein düzeyi düşük ve yüksek peynirlerin sayısı ise 3'er adettir. Özellikle Marmara Bölgesi'ndeki tüm peynirlerin \%66,7'sini orta düzeyde protein değerine sahip peynirlerin oluşturuyor olması dikkat çekicidir.

Tablo 7. Bölgelere Göre Peynirlerin Protein Düzeylerine İlişkin Çapraz Tablo

\begin{tabular}{|l|l|l|l|l|}
\hline \multirow{2}{*}{ Bölgeler } & \multicolumn{3}{|c|}{ Protein Düzeyi } & \multirow{2}{*}{ Toplam } \\
\cline { 2 - 4 } Doğu Anadolu & Düşük & Orta & Yüksek & 5 \\
Güneydoğu Anadolu & 1 & 3 & 1 & 2 \\
İç Anadolu & 0 & 2 & 0 & 2 \\
Ege & 0 & 1 & 1 & 1 \\
Marmara & 0 & 1 & 0 & 9 \\
Akdeniz & 2 & 6 & 1 & 1 \\
Karadeniz & 0 & 1 & 0 & 1 \\
\hline & 0 & 1 & 0 & 21 \\
\hline
\end{tabular}

Yapılan analizlerin sonucunda, araştırma kapsamındaki peynirlerin 8 adetinin düşük tuz oranına, 9 adetinin ise yüksek tuz oranına sahip olduğu görülmüştür. Özellikle Marmara Bölgesi'ndeki peynirlerin \%66,7'sinin yükssek ve çok yüksek tuz oranına sahip olması dikkat çekmektedir. Diğer taraftan Güneydoğu Anadolu Bölgesi’nde bulunan 2 peynirinde düşük düzeyde tuz oranına sahip olduğu tespit edilmiştir. Ayrıca Türkiye genelinde düşük tuz oranına sahip peynir $(\% 38,1)$ oranı ve yüksek tuz oranına sahip peynirlerin $(\% 42,9)$ oranlarının birbirlerine yakın oldukları söylenebilir.

Tablo 8. Bölgelere Göre Peynirlerin Tuz Oranlarına İlişkin Çapraz Tablo

\begin{tabular}{|l|l|l|l|l|l|}
\hline \multirow{2}{*}{ Bölgeler } & \multicolumn{3}{|c|}{ Tuz Oranı } & \multirow{2}{*}{ Toplam } \\
\cline { 2 - 5 } & Düşük & Orta & Yüksek & $\begin{array}{l}\text { Çok } \\
\text { Yüksek }\end{array}$ & \\
\hline Doğu Anadolu & 4 & 0 & 1 & 0 & 5 \\
Güneydoğu Anadolu & 2 & 0 & 0 & 0 & 2 \\
İç Anadolu & 0 & 0 & 2 & 0 & 2 \\
Ege & 0 & 1 & 0 & 0 & 1 \\
Marmara & 2 & 1 & 5 & 1 & 9 \\
Akdeniz & 0 & 0 & 1 & 0 & 1 \\
Karadeniz & 0 & 1 & 0 & 0 & 1 \\
\hline
\end{tabular}




\begin{tabular}{|l|l|l|l|l|l|} 
Toplam & 8 & 3 & 9 & 1 & 21 \\
\hline
\end{tabular}

Diğer taraftan yapılan analizler sonucunda Türkiye'de üretilen ve çalışma kapsamında bulunan peynirlerin 11 tanesinin doymuş yağ miktarlarının orta düzeyde, 6 tanesinin düşük düzeyde olduğu tespit edilmiştir. Diğer taraftan doymuş yağ miktarının yüksek olduğu peynir sayısı ise 4 olarak belirlenmiştir. Çalışma kapsamındaki peynirlerin \%52,4'ü orta düzey doymuş yağ miktarına, \%28,6'sı ise düşük doymuş yağ oranına sahiptir. Çalışma kapsamındaki peynirlerin yalnızca \%19'u yüksek doymuş yağ miktarına sahiptir. Ayrıca İç Anadolu Bölgesi’nde üretilen ve çalışmada yer alan 2 adet peynirden birinin yüksek diğerinin ise orta düzeyde doymuş yağ miktarına sahip olduğu belirlenmiştir. Marmara Bölgesi'nde ise yoğun olarak orta düzeyde doymuş yağ miktarına sahip peynirlerin üretildiği söylenebilir.

Tablo 9. Bölgelere Göre Peynirlerin Doymuş Yağ Miktarına İlişkin Çapraz Tablo

\begin{tabular}{|l|l|l|l|l|}
\hline \multirow{2}{*}{ Bölgeler } & \multicolumn{3}{|c|}{ Doymuş Yağ Miktarı } & \multirow{2}{*}{ Toplam } \\
\cline { 2 - 5 } Doğu Anadolu & Düşük & Orta & Yüksek & 5 \\
Güneydoğu Anadolu & 2 & 2 & 1 & 2 \\
İç Anadolu & 1 & 1 & 0 & 2 \\
Ege & 0 & 1 & 1 & 1 \\
Marmara & 0 & 1 & 0 & 1 \\
Akdeniz & 2 & 5 & 2 & 1 \\
Karadeniz & 1 & 0 & 0 & 1 \\
\hline \multicolumn{2}{|l|}{} & 0 & 0 & 21 \\
\hline
\end{tabular}

Çalışmanın sınırlılıklarında belirtildiği üzere bu araştırmada sadece besin değerleri objektif olarak analiz edilmiş peynirlere yer verilmiştir. Ancak en çok peynir çeşidinin hayvancılığın da gelişmiş olduğu Doğu Anadolu Bölgesi’nde olduğu görülmüştür. Türkiye'de üretilen yöresel peynirlerin besin değerleri karşılaştırıldığında en yüksek enerji değerine Trakya eski kaşar peyniri (424 kcal/100 g) ve en düşük enerji değerine Erzurum civil peyniri (146 kcal/100 g) sahip olduğu görülmüştür.

\section{Sonuç ve Öneriler}

Peynir üretiminde ve çeşitliliğinde birçok faktör öne çıkmaktadır. Örneğin kullanılan sütün cinsi (inek, koyun, keçi), pıhtı oluşturma yöntemleri (asit, şirden, maya), kullanılan yağ oranı (tam yağlı, az yağlı gibi.), tuz oranı (az tuzlu, tuzlu, tuzsuz), sütün işlem görmesi (pastörize, çiğ), kullanılan otlar ve baharatlar, olgunlaşma süresi (olgun, taze) (Özkaya ve Akgün, 2008: 38). Bunların yanı sıra iklim, hava sıcaklığı, alışkanlıklar, doğal mikroflora, gelenekler, imkanlar gibi birçok etken ile peynir çeşitliği gelişmiştir. Peynir üretiminde günümüz teknolojileri sayesinde endüstrileşmeye gidilmiştir talep yoğunlaştıkça yöresel üretim tekniğinden çıkılıp 
makineleşmeye gidilmiştir. Ülkemiz peynir konusundan ihracatta da oldukça talep görmekte ve her yıl düzenli bir şekilde artış görülmektedir.

Değişik yiyecekleri tüketme ve yeni yerleri görme ihtiyacı ve merakı giderek artan kişilere sunulan yeni alternatiflerden birisi de peynir turizmi olmuştur. Peynir turizmi Fransa ve İtalya gibi peynir endüstrisinin gelişmiş ülkelerde bir turizm çeşidi haline gelmiş olup bu turizm çeşidini şarap turizmi tetiklemiştir. Oluşturulan peynir gezi rotaları sayesinde yerli ve yabancı turistlerin merakı bu turizm çeşidine ilgi giderek artmaktadır.

Yapılan bu çalışmada, ülkemizdeki peynir çeşitliliği derlenmiş ve var olan kültürel zenginliklerimizle oluşturulabilecek muhtemel peynir gezi noktaları bölgesel olarak verilmiştir. Ülkemizde hem hammadde olarak süt kaynağının varlı̆̆ı, hem yöresel olarak çeşitliliğin zenginliği, hem de ülkemizin doğal kültürel varlıklar sayısı peynir turizminin geliştirilmesi ve peynir rotalarının oluşturulması, yerel kalkınma için büyük ekonomik gelir ve sürdürülebilirlik sağlayacağı düşünülmektedir.

Araştırma sonucunda gastronomi turizmi kapsamında turizm hareketleri içerisinde yer alacak turistlerden, yağlı peynir sevenler için İç Anadolu ve Marmara bölgelerini ziyaret etmeleri önerilebilir. Ayrıca yarım yağlı peynir sevenlerin Doğu Anadolu, Güneydoğu Anadolu, Ege ve Marmara bölgelerini ziyaret etmeleri önerisinde bulunulabilir. Az yağlı peynir sevenler için ise Güneydoğu Anadolu, İç Anadolu, Marmara ve Karadeniz bölgelerine yönelik ziyaret gerçekleştirmeleri önerilebilir. Yağsız peynir rotası takip etmek isteyenlere ise Doğu Anadolu ve Akdeniz bölgeleri önerilmektedir.

Diğer taraftan peynir tüketiminde protein oranına önem veren gastronomi amaçlı turizm hareketlerine katılan turistlere, Türkiye'nin bütün bölgeleri önerilebilir. Çünkü tüm coğrafi bölgelerin hepsinde en az bir adet orta düzey protein içeren peynir mevcuttur. Ancak bu alanda yine de 6 orta düzey protein içeren peyniri bulunan Marmara Bölgesi ön plana çıkmaktadır. Doğu Anadolu Bölgesi 3 adet orta düzey protein içeren peynirle ikinci sıradadır. Yüksek düzeyde protein içeren 3 peynir mevcuttur. Söz konusu 3 peynir Doğu Anadolu, İç Anadolu ve Marmara bölgelerinde üretilmektedir.

Peynir tüketimi konusunda çeşitli nedenlerle tuz oranını önemseyen gastronomi amaçlı turizm hareketlerine katılan turistlerden az tuz oranlı peynirleri tercih edenlere Doğu Anadolu, Güney Doğu Anadolu ve Marmara bölgeleri önerilebilir. Ancak daha tuzlu peynirleri tercih edenlere ise İç Anadolu ve Marmara bölgelerini ziyaret etmeleri önerilmektedir.

Peynir tüketimi konusunda doymuş yağ oranını dikkate alan ve gastronomi turizmi çerçevesinde turizm hareketlerine katılan turistler için Doğu Anadolu, Güneydoğu Anadolu Marmara ve Akdeniz bölgelerini ziyaret etmeleri önerilebilir. Çünkü bu bölgelerde doymuş yağ oranı düşük peynirler mevcuttur. Ancak neredeyse bütün bölgelerde orta düzeyde doymuş yağ miktarına sahip peynir mevcuttur. Diğer taraftan Doğu Anadolu, İç Anadolu ve Marmara Bölgelerinde doymuş yağ miktarı yüksek peynirlerde bulunmaktadır. 
Bu çalışma sonrasında farklı yiyecekler ve kültürel mirasları içeren gezi rotaları ve haritaları geliştirilebilir ve turizm literatürüne yeni ve alternatif olanaklar sunulabilir. $\mathrm{Bu}$ araştırma besin değerleri analiz edilmiş peynirler üzerine yapılmıştır. Besin değerleri objektif olarak belirlenmiş peynirlerin sayısı toplam peynirler arasında düşük düzeydedir. Bu nedenle yöresel peynirlerin besin değeri analizinin bilim insanları ve kurumlar tarafından yapılması peynir rotalarının daha detaylı ve nitelikli olarak belirlenmesi için gereklidir. Söz konusu paydaşların besin değeri analizlerini yapması önerilmektedir. Ayrıca peynirlerin tatlarını içeren ve betimleyen çalışmalarında yapılması peynir rotalarının belirlenmesinde niteliği artırabilir. Bundan sonra yapılacak çalışmalarda bu konulara dikkat edilmelidir. 


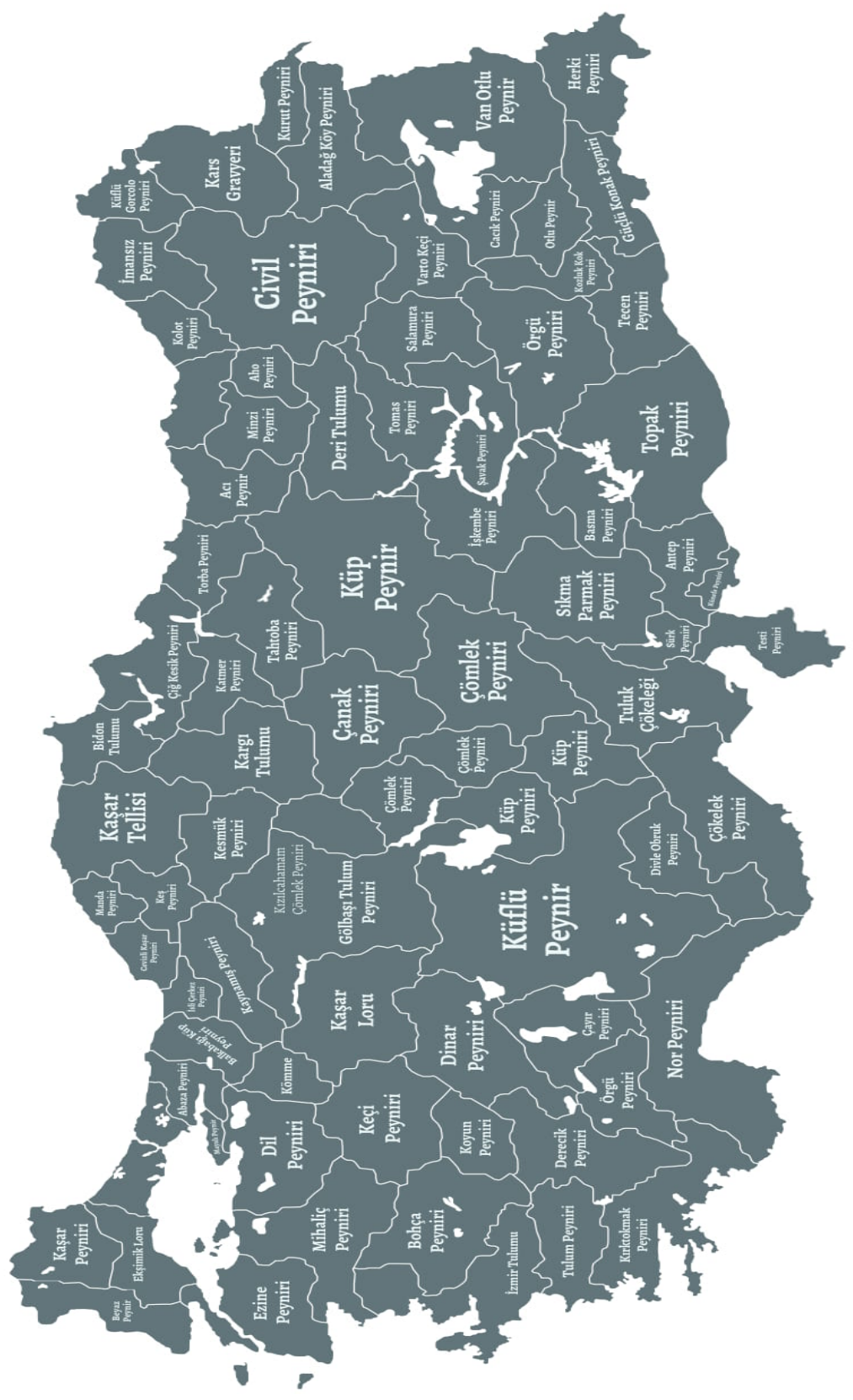

Şekil 1. Türkiye'deki Peynir Çeşitlerinden Bazıları 


\section{Kaynaklar}

Acar, V., ve Karaosmanoğlu, K. (2019). Çerkes Mutfak Kültürünü Deneyimlemeye Yönelik Bir Tur Önerisi: Düzce İli Örneği. Uluslarası Güncel Turizm Araştırmaları, 3(2), 189.

Akar, D., ve Tekinşen, K. K. (2017). Erzincan Tulum Peyniri. Atatürk Üniversitesi Veteriner Bilimler Dergisi, 12(2), 220-222.

Albay, Z., \& Şimşek, B. (2020). Yalvaç'ta Süt ve Süt Ürünleri. Çizgi Kitabevi Yayınları.

Aloğlu, H., Turhan, İ., ve Öner, Z. (2012). Minci (Minzi) Peynirinin Özelliklerinin Belirlenmesi. Gida, 37(6), 1-6.

Altun, İ., ve Köse, Ş. (2016). Geleneksel Kelle Peynirinin Bazı Özelliklerinin Belirlenmesi. Yüzüncü Yll Üniversitesi Tarım Bilimleri.

Andiç, S., Gençcelep, H., ve Tunçtürk, Y. (2010). Dondurak Depolama ve Vakum Amblajlamanın Motal Peynirinde Lipoliz ve Organik Asit Değişimi Üzerine Etkisi. Gida, 35(6), 424-428.

Ardıç, M., Yalçın, S., \& Nizamlığlu, M. (2007). Urfa Peynirinin Bazı Kalite Nitelikleri. Atatürk Üniversitesi Veteriner Bilimleri Dergisi, 2(3), 90-91.

Atış, E., ve Çelikoğlu, Ş. (2017). Boğatepe köyünde geleneksel Kars gravyer ve kaşar peyniri üretiminin yöre ekonomisi ve tanıtımına katkısı. TCK 75. Kuruluş Yll Uluslararası Kongresi, (s. 310-324).

Aygün, O. (2001). Carra (testi) peynirlerinin nitrat ve nitrit düzeyleri. Firat Üniv. Sağllk Bilimleri Derg., 15(2), 331-332.

Ayyıldız, S., ve Şahingöz, A. S. (2018). Gastronomi Turizminde Geleneksel Peynirlerin Yeri; Giresun İli Örneği. 4. Uluslararası Türk Dünyası Turizm Seтроzyumu (s. 403). Kastamonu: Detay.

Bekiroğlu, B. (2019). Türkiye'de Bulunan Peynir Çeşitleri ve Peynir ile Yapılan Yemekler. İstanbul Okan Üniversitesi Sosyal Bilimler Enstitüsü.

Bulut, B. (2006). Çiğ Pastörize Sütten İşlenen Mihaliç Peynirlerinin Kimyasal Bileşimi ve Olgunlaşma Sirasındaki Mikrobiyal Florasındaki Değişimin Belirlenmesi. Selçuk Fen Bilimler Enstitüsü.

Ceyhan, A., Erdoğan, İ., ve Sezenler, T. (2007). Gen Kaynağı Olarak Korunan Kıvırcık, Gökçeada ve Sakız Koyun Irklarının Bazı Verim Özellikleri. Tekirdağ Ziraat Fakültesi, 4(2), 213-215.

Cihangir, E., ve Demirhan, Ö. (2020). Peynir turizmi temelli kültür rotaları oluşturulmasına yönelik bir araştırma: Van. Türk Coğrafya Dergisi, 139-162. 
Çakmakcı, S., Şengül, M., ve Çağlar, A. (1995). Karın Kaymağı Peynirinin Üretim Tekniği ve Bazı Kimyasal Fiziksel Özellikleri. Glda, 20(4), 200-203.

Çalım, D. H. (2007). Konya ve Çevresinde Farkl Tip Ambalajlarda Tüketime Sunulan Tulum Peynirlerinin Kalite Nitelikleri. Selçuk Üniversitesi Besin Hijyeni ve Teknolojisi Anabilim Dalı.

Doğan, N. (2012). Siirt İlinde Üretilen "Siirt Otlu Peynirinin" Bazı Özelliklerinin Belirlenmesi. Harran Üniversitesi Gıda Mühendisliği Anabilim Dalı.

Durusoy, Y. Y. (2017). Coğrafi İsaretli Gastronomik Ürünlerin Bölge Halkı Tarafindan Algılanması Üzerine Analitik Bir Araştırma Kars Kaşarı Örneği. Haliç Üniversitesi Sosyal Bilimler Enstitüsü.

Erbay, Z., Koca, N., ve Üçüncü, M. (2010). Hellim Peynirinin Bileşimi ile Renk ve Dokusal Özellikleri Arasındaki İlişkiler. Gıda, 35(5), 1-7.

Ercan, D. (2009). Quality Characteristics Of Traditional Sepet Cheese. İzmir Institute of Technology.

Ergin, D. B., ve Koca, N. (2019). Toprağa Gömerek veya Buzdolabı Koşullarında Olgunlaştırmanın Sivas Küp Peynirinin Özellikleri Üzerine Etkisi. Gıda, 44(2), 249252.

Eroğlu, A. (2011). Ege Bölgesinde Tüketilen Bazı Geleneksel Peynirlerdeki Aflotoksin M1 Düzeylerinin Belirlenmesi. Celal Bayar Üniversitesi Fen Bilimler Enstitüsü.

Fox, P. (1993). Cheese: Chemistry, Physics and Microbiology.

Güldemir, O., ve Ișık, N. (2011). Nevșehir Mutfak Kültürü ve Yemekleri. Uluslararası Nevşehir Tarih ve Kültür Sempozyumu. 6, s. 5-6. Nevşehir Üniversitesi, Nevşehir.

Gün, İ. (2012). Alternatif Kllıf Uygulamalarının Tulum Peynirinin Bazı Nitelikleri Üzerine Etkisi. Süleyman Demirel Üniversitesi Fen Bilimleri Enstitüsü.

Güzeller, N., ve Koboyeva, F. (2020). Doğu Anadolu Bölgesi'nde Üretilen Peynir Çeşitleri. Osmaniye Korkut Ata Üniversitesi Fen Bilimleri Enstitüsü Dergisi, 3(2), 174-180.

Kalender, M., ve Güzeller, N. (2013). Anamur Yöresi Keş Çeşitleri ve Bazı Kimyasal Özellikleri. Çukurova Üniversitesi Ziraat Fakültesi Dergisi, 28(2), 1-10.

Kamber, U. (2007). The Traditional Cheeses of Turkey: The Aegean. Food Reviews International, 24(3), 1-24.

Kamber, U., ve Çelik, H. T. (2007). Some Microbiological And Chemical Characteristics Of Gorcola Cheese. Yüzüncü Yll Üniversitesi Veteriner Fakültesi, 18(1), 1-6. 
Kamber, U., ve Terzi, G. (2008). The Traditional Cheeses of Turkey: Middle and. Food Reviews International, 24(1), 95-115.

Kan, M., Gülçubuk, B., Kan, A., ve Küçükçongar, M. (2010). Coğrafi işaret olarak Karaman Divle Tulum Peyniri. Karamanoğlu Mehmetbey Üniversitesi Sosyal ve Ekonomik Araştırmalar Dergisi, 15-23.

Karacaoğlu, S., Köşker, H., ve Yenipınar, U. (2014). Turizmde Yerel Yiyeceklerin Önemi ve Coğrafi İşaretleme: Van Otlu Peyniri. Journal of Tourism and Gastronomy Studies, 15-17.

Keskin, B. (2019). Geleneksel Yaprak Peynirinin Bazı Karakteristik Özelliklerinin Tespit Edilmesi ve Olgun Peynirin Gıda Güvenilirliği Açısından Değerlendirilmesi. Harran Üniversitesi Fen Bilimler Enstitüsü.

Kılıç, S. (2013). Aho Peynirinin Fiziksel, Kimyasal ve Mikrobiyolojik Özelliklerinin Belirlenmesi. Samsun: Ondokuz Mayıs Üniversitesi Fen Bilimler Enstitüsü.

Kılıç, S., Uysal, H., Kavas, G., Kesenkaş, H., ve Akbulut , N. (2002). Pilot tesis koşullarında pastörize keçi sütünden çimi peyniri üretimi. Ege Üniversitesi Ziraat Fakültesi Dergisi, 39(3), 56-58.

Kılınçlı, B. (2019). Kars Ardahan İllerinde Üretilerek Satışa Sunulan Türkmen Saçak Peynirinin Kalite Özellikleri. Çukurova Üniversitesi Sosyal Bilimler Enstitüsü.

Kınık, Ö., Ergüllü, E., ve Akbulut, N. (1999). Sepet Peyniri Üretimi ve Kimi Özellikleri Üzerine bir Araştırma. Glda, 24(3), 152.

Kiraz, Ş. (2018). Çorum Yöresinde Üretilen Geleneksel Kargı Tulum Peynirlerinin Bazı Bileşim Özelliklerinin Belirlenmesi. Hitit Üniversitesi Fen Bilimler Enstitüsü.

Korucu, D. (2012). Tomas Peynirinde İzole Edilen Laktik Asit Bakterilerinin Tanımlanması. Namık Kemal Üniversitesi Fen Bilimleri Enstitüsü.

Morul, F. (2011). Divle Tulum Peynirinin Kimyasal ve Mikrobiyolojik Özellikleri. Yüzüncü Yıl Üniversitesi Sağlık Bilimleri Enstitüsü.

Okur, Ö. D. (2010). Geleneksel Dolaz Peyniri Ürün Karakteristiklerinin Belirlenmesi ve Üretim Standardizasyonu. Süleyman Demirel Üniversitesi Fen Bilimler Enstitüsü.

Öründü, S. (2016). Tel Peynirinin Olgunlaşma Kriterlerine Starter Kültürün Etkisinin Araştırılması. Ordu Üniversitesi Fen Bilimleri Enstitüsü.

Özdemir, G., ve Dülger Altıner, D. (2018). Türkiye'de Üretilen Coğrafi İşaret ile Tescillenmiş Peynir Çeşitleri. Uluslararası Gastronomi Turizmi Araştırmaları Kongresi, (s. 1-11). Kocaeli. 
Özgeren, E., ve Seçkin, K. (2012). Türkiye'de Ticari Ölçekte Üretilen Bazı Küflü Peynirlerin Kalite. Akademik Glda, 10(2), 56-57.

Özkaya, D., ve Akgün, F. (2008). Anadoluda Peynir Kültürü. Uluslararası Asya ve Kuzey Afrika Çalışmaları. Ankara: Icanas 38.

Özkaya, D., Akgün, F., ve Gün, İ. (2008). Anadoluda Peynir Kültürü. Uluslarası Asya ve Kuzey Afrika Çalışmaları Kongresi. Ankara: Icanas 38.

Saygı1l, D., Demirci, H., ve Samav, U. (2020). Coğrafi İşaretli Türkiye Peynirleri. Aydın Gastronomy, 13-19.

Şengül, M., Erkaya, T., ve Ceyhun, A. E. (2011). Karın Kaymağı Peynirinin Yağ Asidi Kompozisyonu. Atatürk Üniversitesi Ziraat Fakültesi Dergisi, 42(1), 57-58.

Tarakçı, Z., Bölük, M., ve Karaağaç, M. (2015). Ordu İlinde Tüketicilerin Peynir Tüketim Alışkanlıkları. Ordu Üniv. Bil. Tek. Derg, 55-62.

Tekinşen, K. K. (2001). Maraş Peyniri Üretiminde Baskılama Ağıllığı ve Haşlama Suyu. Doktora Tezi, Selçuk Üniversitesi.

Uysal, Ş. (2008). Dil Peynir Üretiminde Doğal Termofilik Peyniraltı Suyu (Pas) Kültürünün Kullanım Olağanının Araştırılması. Harran Üniversitesi Fen Bilimleri Enstitüsü.

Yalınız, F. (2019). Gaziantep Mutfağında Antep Peynirinin Kullanım Alanları. Avrasya Sosyal ve Ekonomi Araştırmaları Dergisi, 6(6), 658-662. 